\title{
EXPERIMENTAL EVALUATION OF \\ CID PACKAGE HYDRODYNAMIC BEHAVIOR AND \\ RECOMMENDATIONS FOR IMPROVED LOWERING TECHNIQUES
}

by

H. 0. Berteaux

R. G. Walden

P. R. Clay

and

R. E. McDevitt

WOODS HOIE OCEANOGRAPHIC INSTITUTION

Woods Hole, Massachusetts 02543

May 1983

TECHNICAL REPORT

Prepared for the Office of Naval Research under Contract N00014-72-C-0019.

Reproduction in whole or in part is permitted for any purpose of the United States Government. This report should be cited as: Woods Hole Oceanographic Technical Report WHOI 83-21.

Approved for public release; distribution unlimited.

Approved for Distribution:

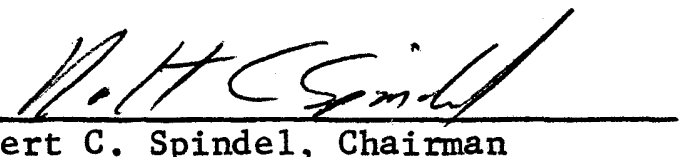


ERRATA

On the Cover Sheet - May 1983 should be July 1983

On the Cover and the Cover Sheet -

Contract Number should be

$\underline{\mathrm{N} 00014-82-\mathrm{C}-0019}$ 
Abstract

1.0 Background 1

2.0 Actual Measurements of CTD Package Terminal Velocity 5

2.1 Instrumentation 5

2.2 Procedure 7

$\begin{array}{lll}2.3 & \text { Results } & 7\end{array}$

$\begin{array}{lll}3.0 & \text { Scale Model Tests } & 12\end{array}$

3.1 Criteria of Flow Similarity 13

3.2 Design and Construction of Scale Mode1 16

3.3 Mode1 Test Procedure 18

3.4 Test Results and Conclusions 20

4.0 Sea Tests 22

4.1 Objectives 22

4.2 Instrumentation $\quad 22$

4.3 Procedure 25

4.4 Data Brocessing 26

4.5 Sea Tests Results $\quad 27$

5.0 Recommendations 31

5.1 Modus Operandi 31

5.2 Improving CTD Package 33

$\begin{array}{lll}5.3 & \text { Improving Lowering Equipment } & 35\end{array}$

6.0 References 39

Appendices

Appendix 1. Maximum Sheave Speed and Estimated Terminal Velocity of CTD Cable

Appendix 2. Mathematical Model of CTD Package Dynamics

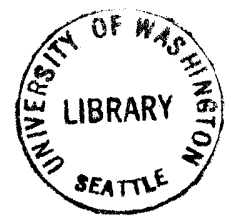




\section{List of Figures}

Figure No.

1.

2.

3.

4.

5.

6.

7.

8.

9.

10.

11.

12.

13.

14.
Caption

Ship lowering CTD instrument package

CTD instrument package

Instrument to measure terminal velocity

Standard WHOI CTD package

Compact CTD package

Curves of depth versus time of two free falling

CTD packages

CTD half scale model

Test instrumentation schematic

Records of tension and pressure measurements

( $R / V$ OCEANUS Cruise 112)

Curves of peak tension versus cable length

Curves of winch payout versus heave and roll

Servo controlled winch schematic

Section of CTD pressure record

Mathematical model of CTD/cable system 


\section{ABSTRACT}

This report is the last of a series of three reports on a comprehensive study of CTD instrument lowering mechanics. The first report, WHOI 79-81, "A Study of CTD Cables and Lowering Systems", examines the causes and modes of lowering cable failures, both mechanical and electrical, and makes recommendations to improve existing instrument packages and lowering procedures. The second report, WHOI 81-76, "Hydrodynamics of CTD Instrument Packages", is a theoretical study of instrument package stability when cable lowered or free falling. The model is used to predict the hydrodynamic response of CTD packages in their present or improved configuration. This report, WHOI 83-21, is more factual. It describes the tests performed on scale models and actual CTD packages to actually observe and/or measure their hydrodynamic behavior. Analytical results and experimental data obtained in this study are used to draw recommendations for CTD package improvement and future lowering procedures. 


\section{ACKNOWLEDGEMENTS}

The authors want to express their gratitude to Mr. R. Reiniger and Mr. J. G. Desureault of the Bedford Institute of Oceanography (Canada), who kindly shared their experience and knowledge in measurements of CTD behavior, in CTD packaging improvements and in ship motion compensation devices.

The excellent work of Mr. P. O'Malley who built the CTD scale models and provided technical assistance throughout the dock and tank tests deserves a special mention.

The assistance of Mrs. C. Muzzey and of the Graphic Arts Group in typing and preparing this report is also gratefully acknowledged.

The work hereafter reported received support from the Office of Nava1 Research, under Contract N00014-72-C-0019. 
Frequent failures of cables used for lowering instrument packages from vessels at sea (Figure 1) have prompted a study to identify the causes of these failures and to recommend improvements in materials, handling equipment and procedures. While this study was specifically concerned with Conductivity, Temperature and Depth (CTD) packages it has relevance to many cable lowered packages. A typical CTD instrument package is shown in Figure 2.

The first part of the study (Berteaux et al, 1979) examined the causes and modes of cable failure both mechanical and electrical. Failures as a consequence of high tensile loads, fatigue, corrosion, mishandling, shock loads, cross winding and jumped sheaves were identified. Methods to improve the reliability of CTD cables and lowering systems were proposed. This included quality control and acceptance testing procedures for new cables and instructions for installing these cables aboard ship. Proper maintenance procedures for both cables and winches were also reviewed. Operational limits for both depth of cast and payout speed were calculated for different sea states. Alternate CTD lowering systems using special steel armored cables, synthetic fiber and fiber optics cables were evaluated. The results of this investigation were condensed in a first report (Reference 1). The report concludes with recommendations including a redesign of the CTD instrument package to improve its hydrodynamic performance characteristics.

A second report (Cook 1981, Reference 2) studied the hydrodynamics of CTD instrument packages. In this report an analysis of the standard Woods Hole CTD package was made. Its static stability was investigated with the help of a computer model. The model was used to perform sensitivity 
$\frac{-2}{20}$

$\frac{-2}{20}$

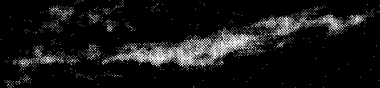

H.

3. 2.24

2

20

4.:.

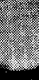

2.0 .02

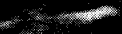

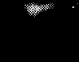

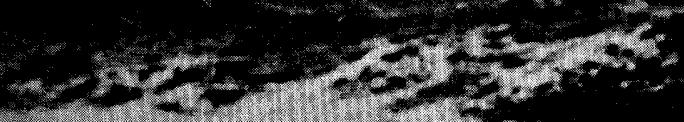

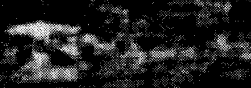

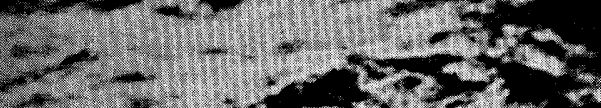

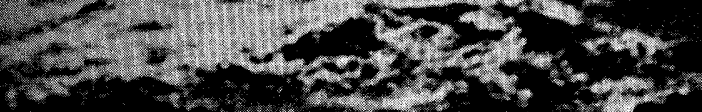

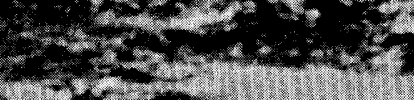

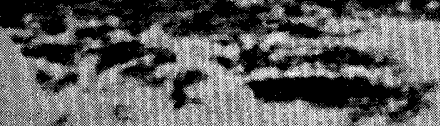

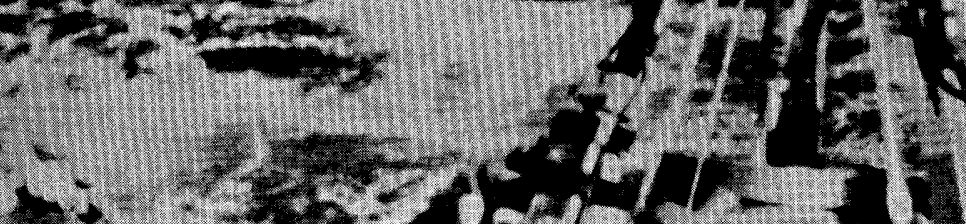

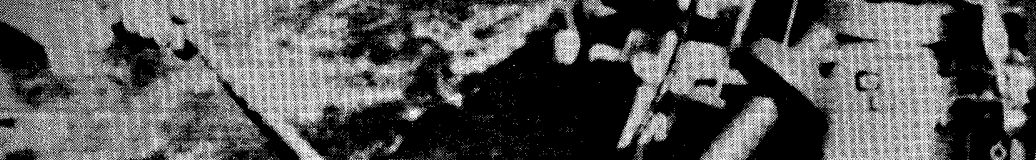
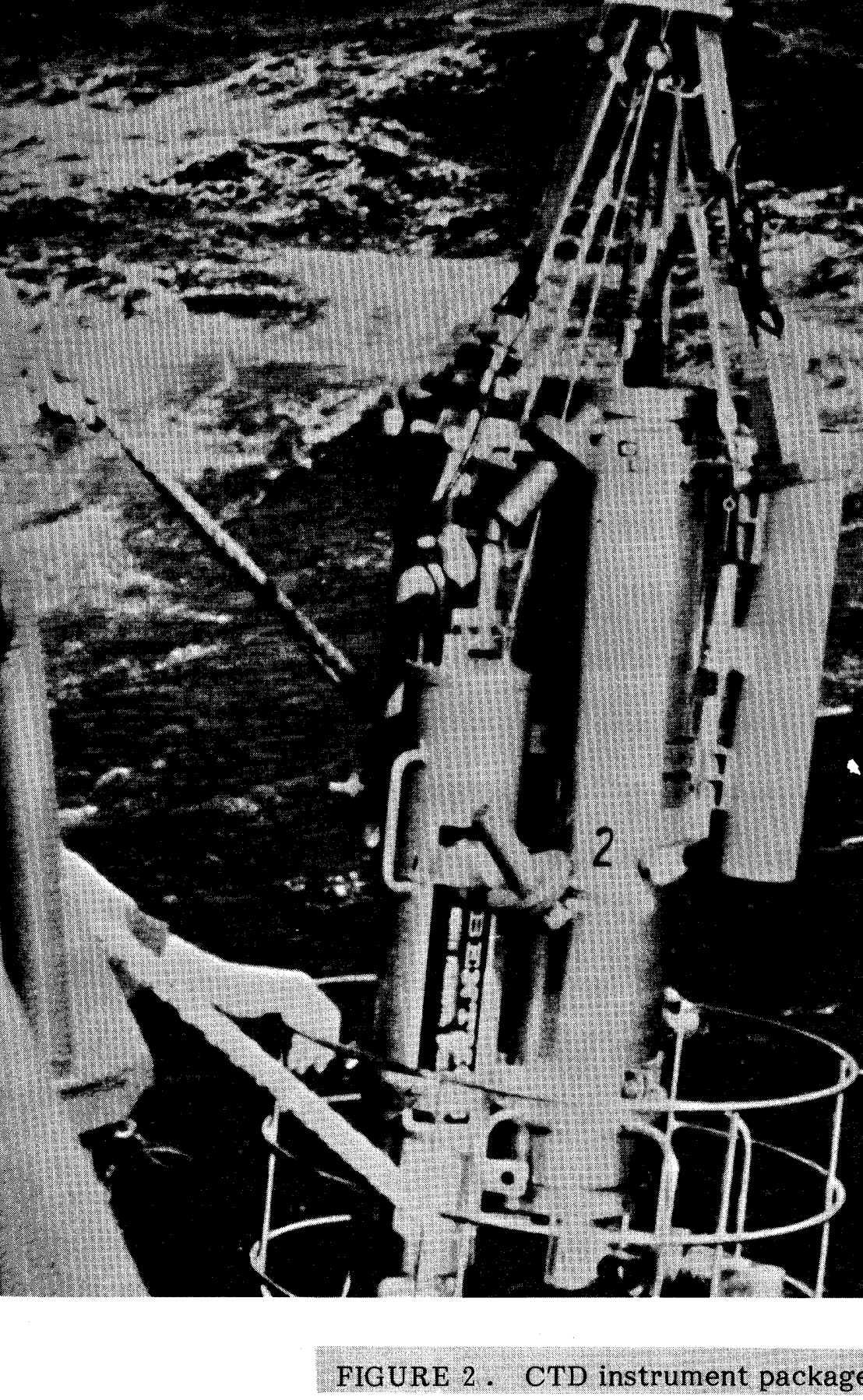
$\lim _{3}$
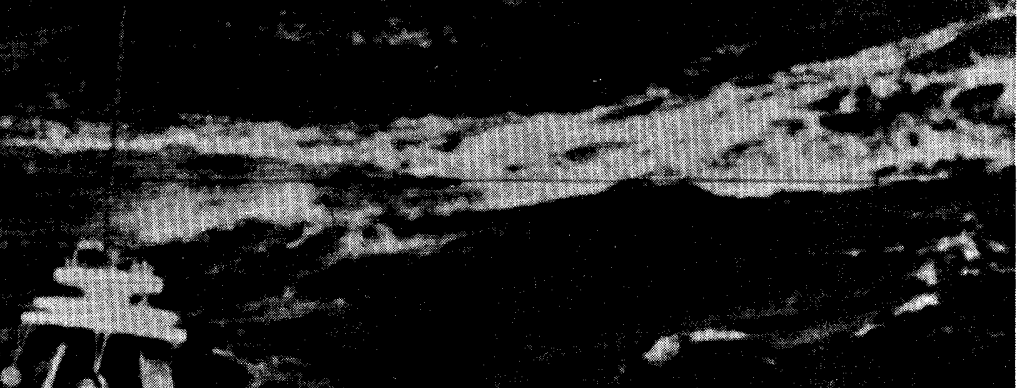
analyses considering modifications to the standard package in symmetry, weight and drag. From this, an optimal configuration was selected. Criteria for the formulation of a half scale model were developed to satisfy geometric, kinematic and dynamic similarity. The report concluded with recommendations to improve the hydrodynamic behavior of the package through an increase in its terminal velocity by changes in symmetry, drag reduction and the addition of weight.

A paper reviewing these studies and presenting the results of tank model tests was published in Deep Sea Research (Berteaux and WaIden, 1983, Reference 3). This paper also presents the results obtained at sea which confirmed our suspicions that conditions of zero tension in the wire did indeed occur when the combination of ship motions and payout speed were too great. Severe wire damage could occur from the subsequent snap loading.

The report which follows concludes our CTD study. It presents in detail the instruments and procedures used to observe and document the hydrodynamic behavior of standard and improved CTD packages. This report also presents a number of recommendations to improve the efficiency and the reliability of instrument lowerings.

The first section describes how the terminal velocity of free falling CTD packages was actually measured. The effects that drag reduction and increased weight have on package terminal velocity are discussed and numerical results presented.

A half scale model of the CTD package was built and its flight pattern observed as it was dropped in the large water tank of the Naval Surface Weapons Center. The second section describes the criteria of similarity used for the fabrication of the mode1; it outlines the test procedures, and reviews the results obtained.

The next section covers the tests performed at sea during actual CTD 
lowerings. It first describes the tests done with a standard CTD package. This package was instrumented to provide simultaneous measurements of package depth, inclination and cable tension at the point of package attachment. Important results obtained with these measurements are reviewed. Comments on the performance at sea of an improved compact CTD package are next presented.

In the final section the report formulates a number of recommendations to improve the efficiency and the reliability of instrument package lowering operations. Prudence and common sense will dictate that limits be set on payout speeds and lengths payed out as a function of sea state. Theoretical considerations and measurements made during the study permit quantifying these limits. Ways of specifically improving CTD packages are discussed. A brief review of ship motion compensation and of its benefits for cable lowering applications concludes this report.

2.0 ACTUAL MEASUREMENTS OF CTD PACKAGE TERMINAL VELOCITY

2.1 Instrumentation

An instrument was constructed to measure actual velocities of CTD packages in shallow water dock tests (Figure 3). The instrument consisted of a lightweight bicycle wheel rim geared through a friction clutch to a fifteen turn linear potentiometer. Small Kevlar line (.045 inch OD) was wound on the rim and attached to the package to be dropped. The potentiometer was connected to a DC power supply and to a strip chart recorder which displayed voltage (distance in this case) versus time. By differentiating, or taking the slope of the distance versus time curve, velocity as a function of time was obtained. Terminal velocity can be determined from the constant slope section of the distance versus time plot. 


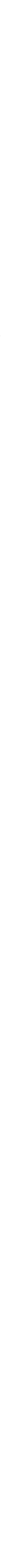

FIGURE 3. Instrument to measure terminal velocity 


\subsection{Procedure}

The operating technique for using this apparatus was to first zero the recorder with the CTD just below the surface. Then adjustments were made in the power supply output until full scale reading was obtained with the package near the bottom. At the dock the water depth is approximately 64 feet. The recorder was turned on just prior to quick releasing of the package.. As the CTD fell, the instrument measured and recorded the distance traveled versus time until a restraining line brought the package to rest a few feet off the bottom. At this time the recorder was shut down.

\subsection{Results}

Early velocity measurements were made of the standard WHOI CID package depicted in Figure 4. This package consisted of a CTD instrument with a 24 inch pressure case, a (24) 1.2 liter bottle rosette sampler, and a pinger all enclosed in a $3 / 4$ inch galvanized steel pipe frame. In water the 90 pound CTD instrument makes up $35 \%$ of the total package immersed weight ( 254 pounds), the 70 pound rosette $28 \%$, the 40 pound pinger $16 \%$ and the 54 pound frame the remaining $21 \%$. Lead pigs clamped to the lower part of the CTD instrument case, were added and changes in terminal velocity of the standard package due to increased weight were measured and recorded.

The standard package was then reconfigured and ballasted to obtain a higher terminal velocity with less weight. The external steel frame was completely removed except for the solid rod, stainless steel frame at the bottom protecting the CTD sensors. This substantially decreased the package hydrodynamic drag. The rosette housing was attached closely to the upper CTD end cap by stand offs further reducing drag. Weight was added to this compact package by clamping a smooth lead sleeve to the lower end of the CID case, as shown in Figure 5. 


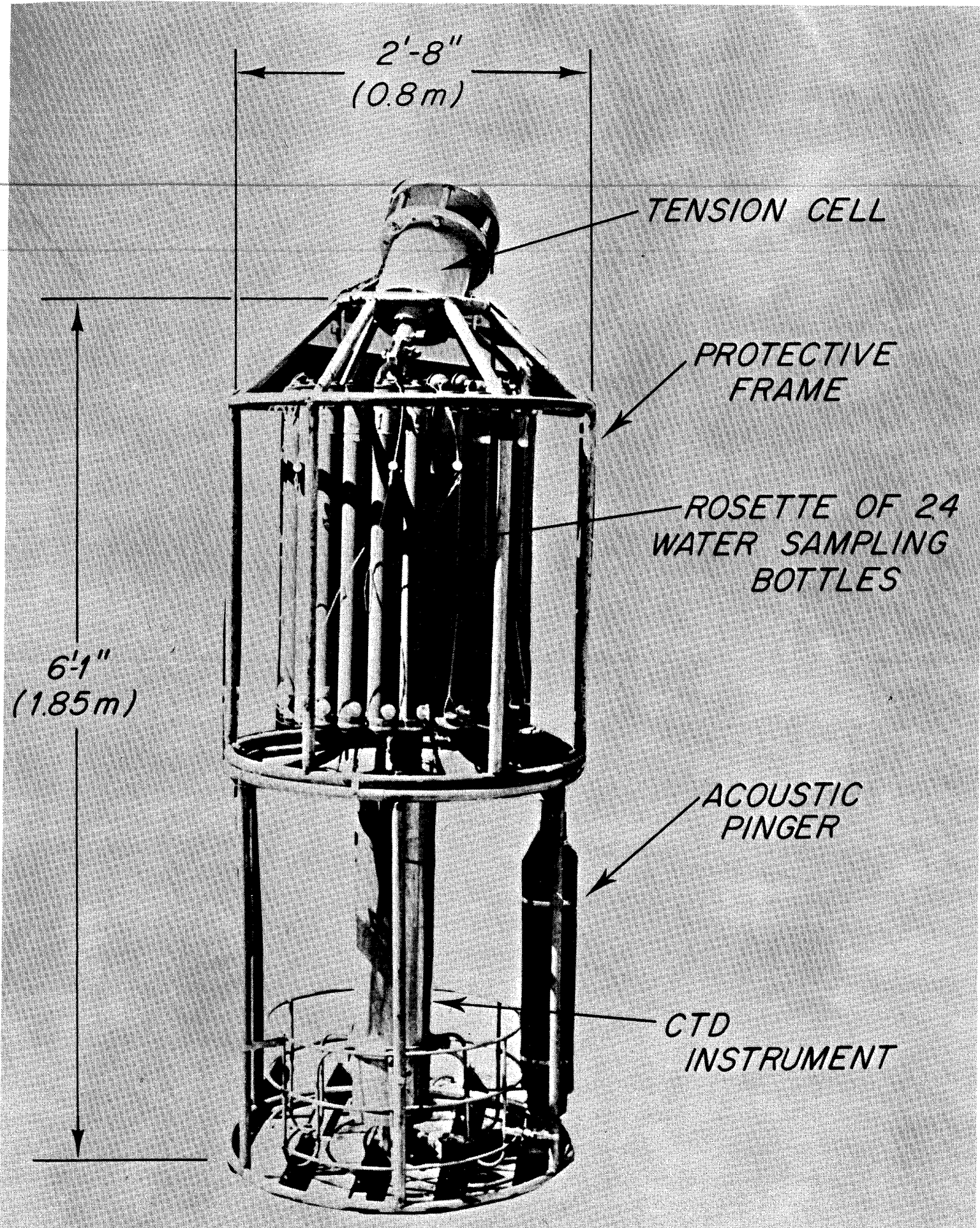

FIGURE 4. Standard WHOI CTD package 


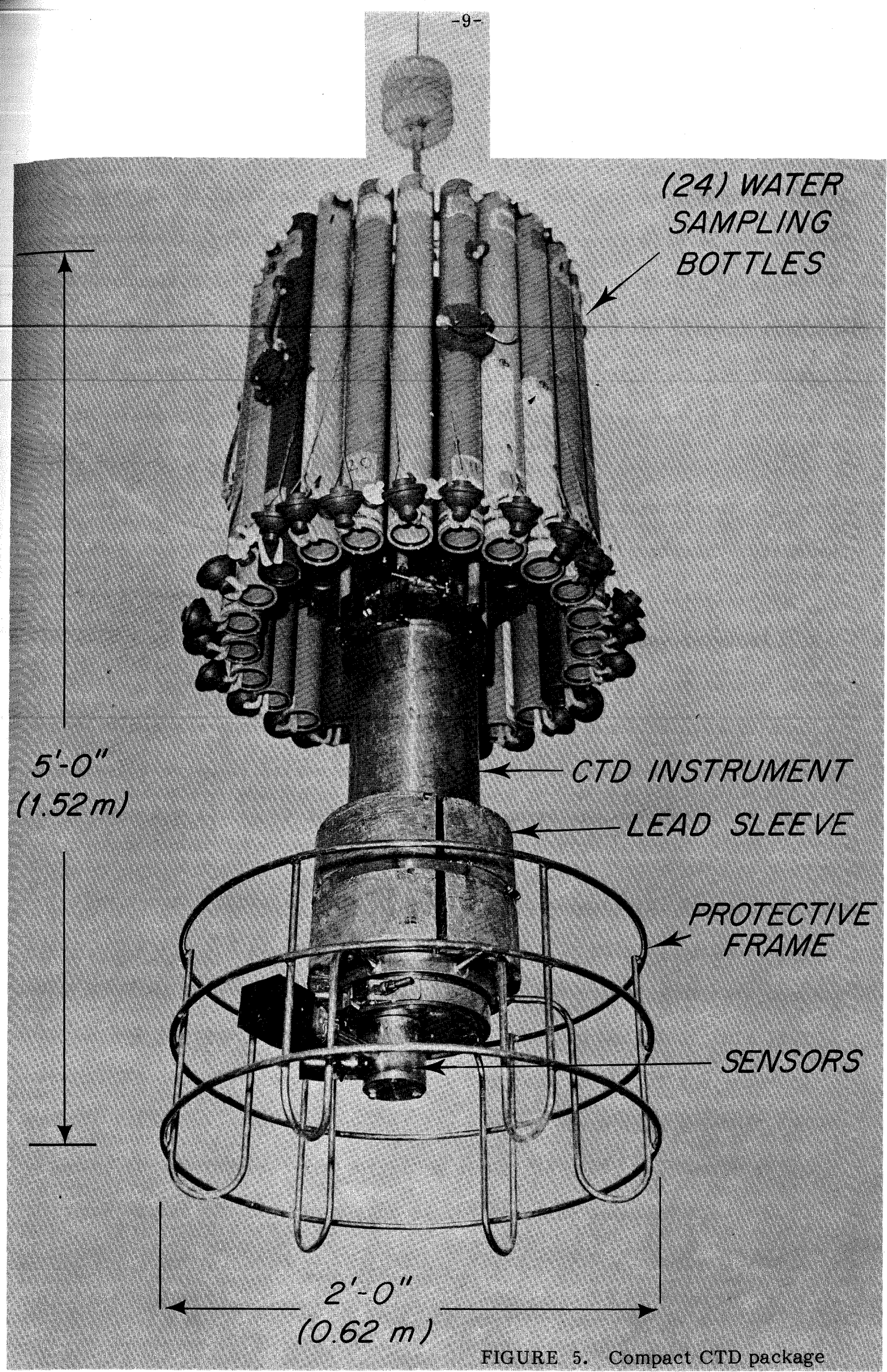


Records of distance (depth) versus time for a standard and a compact CTD package are shown in Figure 6. The full scale depth in this plot is 63.75 feet with a chart speed of one inch per second. The immersed weight of the standard package was 255 pounds with an air weight of 420 pounds. It reached a terminal velocity of $7.59 \mathrm{ft} / \mathrm{sec}$ in about two seconds after drop. A similar trace is shown for the compact version having an immersed weight of 292 pounds and an air weight of 434 pounds. In this case a terminal velocity of $10.8 \mathrm{ft} / \mathrm{sec}$ was reached in just over one second.

Table 1 lists the terminal velocity for five configurations, three for the standard version and two for the compact configuration. Different ballast weights are shown for each version. The results clearly show the effect of increasing weight and decreasing area on the terminal velocity. By adding lead weight in 104 pound wet weight increments to the standard package the $7.59 \mathrm{ft} / \mathrm{sec}$ velocity was increased to $9.04 \mathrm{ft} / \mathrm{sec}$ and finally to $10.31 \mathrm{ft} / \mathrm{sec}$ with 207 pounds of lead added. This increased the terminal velocity by $37 \%$, but also increased the weight to $6481 \mathrm{bs}$ in air.

The compact package, CTD and rosette with no external frame, initially had a velocity of $8.69 \mathrm{ft} / \mathrm{sec}$ with a wet weight of only 125 pounds. By adding a lead sleeve of 167 lbs (wet weight), the velocity of this compact package was increased to $10.8 \mathrm{ft} / \mathrm{sec}$. The immersed weight of this last version(292 1bs) is almost equal to the immersed weight of the standard package (255 1bs). Yet, because of its compact shape, its terminal velocity is $43 \%$ larger. Its weight in air is only $434 \mathrm{lbs}$, which is about the same as the 420 lbs air weight of the standard package. 


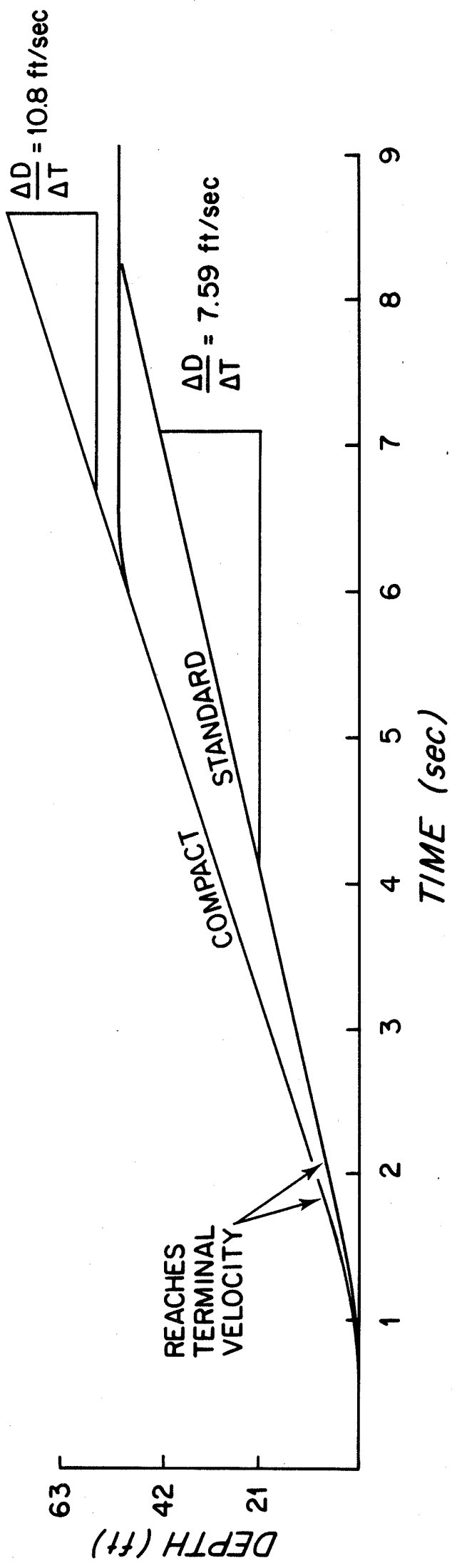

D 
TABLE 1

Standard and Compact CTD Package

Termina1 Velocities

\begin{tabular}{|c|c|c|c|c|}
\hline $\begin{array}{c}\text { Package } \\
\text { Description }\end{array}$ & $\begin{array}{c}\text { Wet } \\
\text { Weight }\end{array}$ & $\begin{array}{c}\text { Air } \\
\text { Weight }\end{array}$ & $\begin{array}{c}\text { Average } \\
\text { Termina1 } \\
\text { Velocity }\end{array}$ & \% Increase in $\mathrm{V}_{\mathrm{T}}$ \\
\hline Standard & 255 & 420 & 7.59 & - \\
\hline $\begin{array}{c}\text { Standard } \\
+(4) \text { lead weights }\end{array}$ & 359 & 538 & 9.04 & $20 \%$ \\
\hline $\begin{array}{c}\text { Standard } \\
+(8) \text { lead weights }\end{array}$ & 462 & 648 & 10.31 & $37 \%$ \\
\hline $\begin{array}{c}\text { Compact } \\
\text { Compact } \\
\text { with lead sleeve }\end{array}$ & 125 & 240 & 8.69 & $15 \%$ \\
\hline
\end{tabular}

Reducing the package frontal area also reduces the amount of entrained water thus improving the package ability to accelerate and to better accomodate ship roll and heave. The large righting moment resulting from the drag forces on the rosette bottles located high above the center of gravity combined with the gravity pull of the lead sleeve low on the CTD produces very stable flight characteristics.

\subsection{SCALE MODEL TESTS}

A series of CTD scale model tests were conducted in July 1981 at the Nava1 Surface Weapons Center (NSWC), Silver Spring, Maryland. The objective of these tests was to observe and record the "flight" pattern of scaled down versions of CTD packages as they were cable lowered and/or allowed to free fall to the bottom of the NSCW vertical tank. This tank is 
15 meters in diameter and 30 meters deep.

\subsection{Criteria of Flow Similarity}

The hydrodynamic behavior of a full scale prototype can be reasonably assessed from tests performed with a scale model provided certain conditions of similarity between prototype and model are reproduced. In short, one must ensure that:

1. The test procedure introduces the same effects on the model.

2. These effects cause the same results.

Criteria of similarity commonly used include:

- Geometric similarity. The model must be a good physical image of the prototype. It must reproduce its shape and also its main physical characteristics. For example identical location of center of buoyancy, center of gravity, similar mass moments of inertia, etc...

- Kinematic similarity which ensures that the streamline pattern remains the same for model and prototype.

- Dynamic similarity, which ensures that model and prototypes are subjected to the same loads. This is accomplished by maintaining the ratios of homologous forces identical for the model and the prototype.

Given the size of the actual CTD package, building a half scale model seemed reasonable and practical. Its weight was determined using the following rationale: 
According to the criterion of dynamic similarity, the ratios of the gravity and drag forces applied to the model and package had to be the same. Using the familiar expression for the drag force

$$
F_{D}=\frac{1}{2} \rho c_{D} \Delta V^{2}
$$

where

$$
e \text { is the fluid density }
$$

$C_{D}$ is the drag coefficient

$A$ is the cross section area given by $A=9 D^{2}$

9 being some geometric constant (i.e. $\pi / 4$ ) and $D$ a characteristic dimension

$\checkmark$ the speed of fall

the ratios equality can be written as:

$$
\frac{W_{M}}{W_{p}}=\frac{C_{p} g_{M} D_{M}^{2} V_{M}^{2}}{C_{D_{p}} g_{p} D_{p}^{2} V_{p}^{2}}
$$

where $\mathrm{W}$ is the immersed weight, and the subscripts $M$ and $P$ refer to model and package respectively.

In flow regimes dominated by inertia and viscous forces, dynamic similarity will also dictate that the Reynold's number be the same for both model and prototype. Both being immersed in water, an equality of Reynold's numbers yields:

$$
V_{M} D_{M}=V_{P} D_{P}
$$

For geometric similarity to prevail

$$
g_{M}=g_{p}
$$

Model and package having the same Reynold's numbers and the same shape, both have the same drag coefficient, thus

$$
C_{D_{M}}=C_{D_{P}}
$$


Introducing equalities $3.2,3.3$, and 3.4 in 3.1 yields

$$
W_{M}=W_{P}
$$

Thus the model immersed weight should equal the immersed weight of the prototype. Introducing the scale ratio $\frac{D_{R}}{D_{M}}=2$ in 3.2 yields

$$
V_{M}=2 V_{P}
$$

A half scale model which falls twice as fast and weighs in water as much as the actual package is not a very practical one. A lighter model traveling at moderate speeds would be easier to handle and to visually observe. In fact such a model may not be as distorted as it may seem. Certainly the flow pattern around the blunt surfaces of the package components is turbulent most of the time. This implies that the drag coefficient remains constant over a large range of Reynold's numbers. If the speed of the model is kept large enough to maintain turbulent flow then its own drag coefficient will equal the drag coefficient of the prototype over the same range of Reynold's numbers. In this case the criterion of dynamic similarity 3.1 reduces to

$$
\frac{W_{M}}{W_{p}}=\left(\frac{D_{M}}{D_{P}}\right)^{2}\left(\frac{V_{M}}{V_{p}}\right)^{2}=\frac{1}{4}\left(\frac{V_{M}}{V_{p}}\right)^{2}
$$

from which

$$
W_{M}=\frac{W_{p}}{4}\left(\frac{V_{M}}{V_{p}}\right)^{2}
$$

The package terminal velocity is of the order of $10 \mathrm{ft} / \mathrm{sec}$. Selecting a speed of model fall equal to the speed of prototype fall - which should be sufficient to maintain turbulent flow conditions - yields

$$
W_{M}=\frac{W_{p}}{4}
$$

To summarize, the model retained would be half scale and would have a submerged weight equal to one quarter of the full scale value. At terminal velocity, the model will have a speed $\mathrm{V}_{M}$ given by

$$
V_{M}=\sqrt{\frac{W_{M}}{C_{D_{M}} A_{M}}}=\sqrt{\frac{W_{p} / 4}{C_{D_{M}} A_{P} / 4}}
$$


which equals the terminal velocity of the package as long as $C_{D M}=C_{D P}$

3.2 Design and Construction of Scale Model

The half scale model was made of removable cylinders attached to a tubular frame (Figure 7). These cylinders had half the diameter and half the length of the components represented. They were placed in the frame at a location similar to the location occupied by the component in the actual package. To maintain correct submerged weight distribution as well as correct weight-to-drag ratios, the material density of each cylinder was calculated according to the following scheme:

1. Measure the immersed weight of the actual component "i", $W_{p}(i)$

2. The immersed weight of the cylinder representing the component "i" is then

$$
W_{m}(i)=W_{p}(i) / 4
$$

3. Compute the volume $\mathrm{VO}_{\mathrm{M}}(i)$ of the cylinder " $i$ "

4. The desired specific weight of the cylinder " $i$ " is then given by:

$$
\begin{aligned}
\rho_{M}(i)= & \left(w_{M}(i)+V O_{M}(i) \rho_{w}\right) / V O_{M}(i) \\
& \rho_{W} \text { BEING THE DENSITY OF SEA WATER }
\end{aligned}
$$

Results obtained following this approach are summarized in Table 2 . 


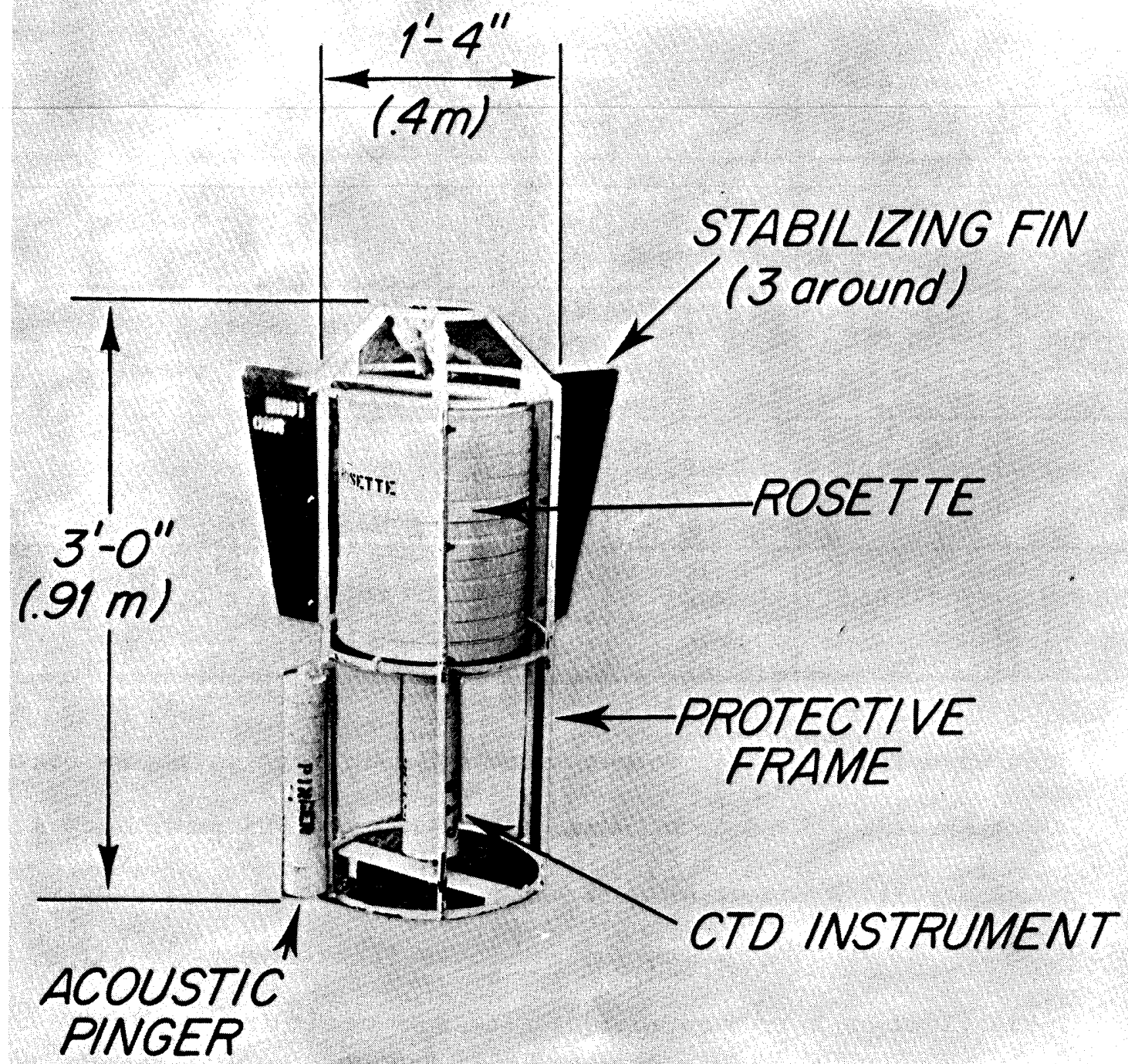

FIGURE 7. CTD half scale model 
TABLE 2

Specifications for $\frac{1}{2}$ Scale CTD Model

\begin{tabular}{|l|c|c|c|c|c|}
\hline $\begin{array}{l}\text { Component } \\
\text { Modeled }\end{array}$ & $\begin{array}{c}\text { Cylinder Dimensions } \\
\text { (inches) } \\
\text { Diam } \times \text { Length }\end{array}$ & $\begin{array}{c}\text { Weight } \\
\text { (1bs) }\end{array}$ & $\begin{array}{c}\text { Immersed } \\
\text { Weight } \\
\text { (lbs) }\end{array}$ & $\begin{array}{c}\text { Specific } \\
\text { Weight } \\
\text { (lbs/cu/ft) }\end{array}$ & $\begin{array}{c}\text { Specific } \\
\text { Gravity }\end{array}$ \\
\hline CTD & $3.5 \times 12.5$ & 29.26 & 24.75 & 415.63 & 6.6 \\
\hline Rosette & $11.5 \times 15.0$ & 65.20 & 17.50 & 83.41 & 1.34 \\
\hline Frame & $\begin{array}{c}\frac{1}{2} \emptyset \text { diam.tubing } \\
\text { Ring \& Verticals } \\
\text { to scale }\end{array}$ & 16.90 & 13.50 & 310.0 & 4.97 \\
\hline Nephelometer & $3.0 \times 16$ & 12.24 & 10.0 & 349.71 & 5.60 \\
\hline
\end{tabular}

The immersed weight of an actual CTD package made up of a CTD instrument, a rosette, a WHOI frame and one pinger was measured to be $2551 \mathrm{bs}$. The immersed weight of the model, using the data shown in the table, is found to be $65.75 \mathrm{lbs}$. or 3.9 as sma 11 as the prototype.

Plates of steel, aluminum, and polyethylene were used to fabricate the model. Circular slabs of these materials were stacked in combinations yielding the proper dimensions, immersed weight, and location of center of gravity for each cylinder.

\subsection{Model Test Procedure}

Models of instrument packages were lowered with the help of an adjustable speed winch. Maximum winch speed exceeded the terminal velocity of al1 model configurations tested thus allowing a number of lowerings to be essentially free fall. 
The lowering cable was made somewhat shorter than the tank depth. The models were attached to the lowering cable by a length of compliant nylon rope which could absorb the kinetic energy of the lowered or free falling specimen at the end of payout. Keeping the winch running in the same (payout) direction simply brought the specimen back to the surface.

The cable was passed through an overhead sheave located above the tank center. A load cell attached to the sheave was used to monitor and record tension during the lowerings.

A11 lowerings were made a constant speed. The lowering speed was inferred from rpm measurements made with a digital tachometer. Typical lowering speeds were $4.3,6.7$, and $10 \mathrm{ft} / \mathrm{sec},(78.6,122.5$ and 182.9 meters/min.).

Flight attitude and deviation from vertical plumb line were observed, noted, and in certain cases filmed with the help of horizontally and vertically mounted underwater cameras. To help visualize the flight path as seen from the top, two yellow polypropylene lines crossing each other at right angles were tied to the tank bottom grid.

Various combinations of instrument models, stabilizing fins and nose cone were used. The different configurations tested included:

- CTD, Rosette, used as "base line".

- CTD, Rosette, Pinger strapped to the frame.

- CTD, Rosette, Pinger, Nephelometer positioned horizontally across the bottom of the frame, on center and off center.

- CTD, Rosette, Nephelometer both on and off center.

- CTD, Rosette, 3 small vertical fins.

- Same as above with 3 large vertical fins.

o Same as above with addition of pinger strapped on the side.

- CTD, Rosette, Pinger, Nose Cone, 3 large fins. 
3.4 Test Results and Conclusions

The following comments summarize the test results:

o Terminal velocities observed agree with terminal velocities predicted.

- At small lowering speeds and therefore high cable tension values al1 configurations behave rather well. Conversely deviations from well behaved plumb line flight could be observed only at high lowering speeds and/or at terminal velocities (free fall).

- At speeds of $6.0 \mathrm{ft} / \mathrm{sec}$ up to terminal velocity $(7.6 \mathrm{ft} / \mathrm{sec})$ the baseline configuration (frame, rosette and CTD instrument casing) is statically stable but dynamically unstable. It falls in a straight line but oscillates back and forth around its c.g. - The pitch amplitude appears to be approximately one CTD diameter and the frequency one hertz.

- Strapping a pinger outside the frame has the following effects:

- It makes the package tilt about ten degrees.

- The added weight causes an increase in terminal velocity.

- The added weight lowers the package center of gravity and increases the distance between package center of gravity and center of buoyancy. As a result the wobbling of the baseline configuration is sensibly reduced but still present. - Strapping a nephelometer across the frame bottom ring produces the following effects:

- The added weight causes an increase in terminal velocity.

- The location of the added weight on the frame bottom considerably increases the distance between package center of buoyancy and center of gravity. As a result the oscillations 
observed in the baseline are totally suppressed.

- Horizontally mounted cylinders seem to induce spin. They

make the package turn around its vertical axis as it travels through water, more turns being induced at higher speed (typically two turns in 100 feet drop at terminal velocity). The addition of a nose cone did produce some unexpected (and spectacular) results.

- It did not cause an increase in terminal velocity.

- It produced static instability resulting in a large radius helical flight path.

- The addition of three equally spaced vertical stabilizing fins resulting in

- Total suppression of baseline oscillations.

- Absolute plumb line vertical flight pattern for concentric (axisymmetrica1) configurations.

- With a pinger attached on the side of the frame the package will fall in a stable straight line, in a direction directly opposite the pinger location, and at an angle with the vertical equal or close to the package initial tilt angle.

- Initial package inclination did not result in package tumbling. Packages would simply straighten their flight back to vertical fall and then resume the flight pattern specific to their particular configurations. This seems to confirm the static stability of al1 configurations tested, except of course for those with a nose cone. 
In summary, with the exception of those configurations with a nose cone, all configurations seem to be reasonably statically stable. Serious tumbling or kiting could not be detected.

Both the baseline and the baseline with a pinger are dynamically unstable, i.e. they wobble around their line of flight. These two configurations are those most often encountered in practice. The oscillations can be reduced and/or suppressed by either lowering the c.g. (add weight close to the bottom) or by adding stabilizing fins. The latter solution however, will force the nonsymmetrical package to fall in a straight line and glide off the vertical. On the other hand adding weight increases the terminal velocity, a desirable result. Based on these results, the following recommendations to improve package configuration and performance can be made:

- Avoid horizontally mounted instruments.

- Avoid or minimize package asymmetry.

- Judiciously add weight at the bottom of the package.

- Reduce package drag by means other than a nose cone.

4.0 SEA TESTS

4.1 Objectives

In order to confirm the motions and tension values predicted through analyses and scale model tests a standard CTD package was modified and taken to sea. Measurements of line tension and package tilt during routine lowerings were desired at various payout speeds and under different sea state conditions to observe the performance of the package.

\subsection{Instrumentation}

A standard CTD was modified to provide tilt in two orthogonal axis and line tension immediately above the package. The tilt meters measure the angle the CTD package makes with the vertical in order 
to determine whether the instrument is tumbling and/or spinning. The meters were positioned at right angles to each other in a plane perpendicular to the long axis of the package nine inches below the top end cap of the CTD. The meters are Humphrey, Inc.'s critically damped pendulum with a range of $\pm 45^{\circ}$. The pendulum drives a wiper across a 2000 ohm potentiometer. As shown in Figure $8 \mathrm{a}$ the tilt sensor outputs a voltage between 0 and 5 volts. This voltage is sensed by a differential amplifier which buffers the input to a 12-bit analog-to-digital converter resulting in a resolution of $.022^{\circ}$. The combined error of both the differential amplifier and the converter is less than $.05^{\circ}$ over the temperature range to which the instrument was exposed. The total accuracy is better than $.1^{\circ}$ for either tilt sensor.

Line tension was measured using a BLH electronics 350 ohm load ce11 modified to permit the use of the cell in an ocean environment to a depth of 7000 meters without error due to ambient pressure effects. The load cell has a range of 0 to 5800 pounds and infinite resolution. The maximum error from all causes is . $2 \%$ of rated output over the temperature range the instrument was exposed to. As shown in Figure $8 \mathrm{~b}$ the output from the load cell is amplified 667 times to give a 0 to $10 \mathrm{~V}$ output for a load of 0 to 4000 lbs. This output is buffered by a differential amplifier into a 12-bit analog-to-digital converter resulting in a resolution of one pound and a total system accuracy of within \pm 10 pounds.

The depth velocity and acceleration of the CTD package is determined from differentiation of the normal pressure sensor output of the CTD. It is a 350 ohm bonded transducer manufactured by Paine Instruments. Its output is amplified a hundred times and then converted into a 16-bit binary number. The CTD package used has a pressure range of 0 to 6500 dbar and a resolution of 0.1 dbar. The accuracy is \pm 6.5 dbar. 

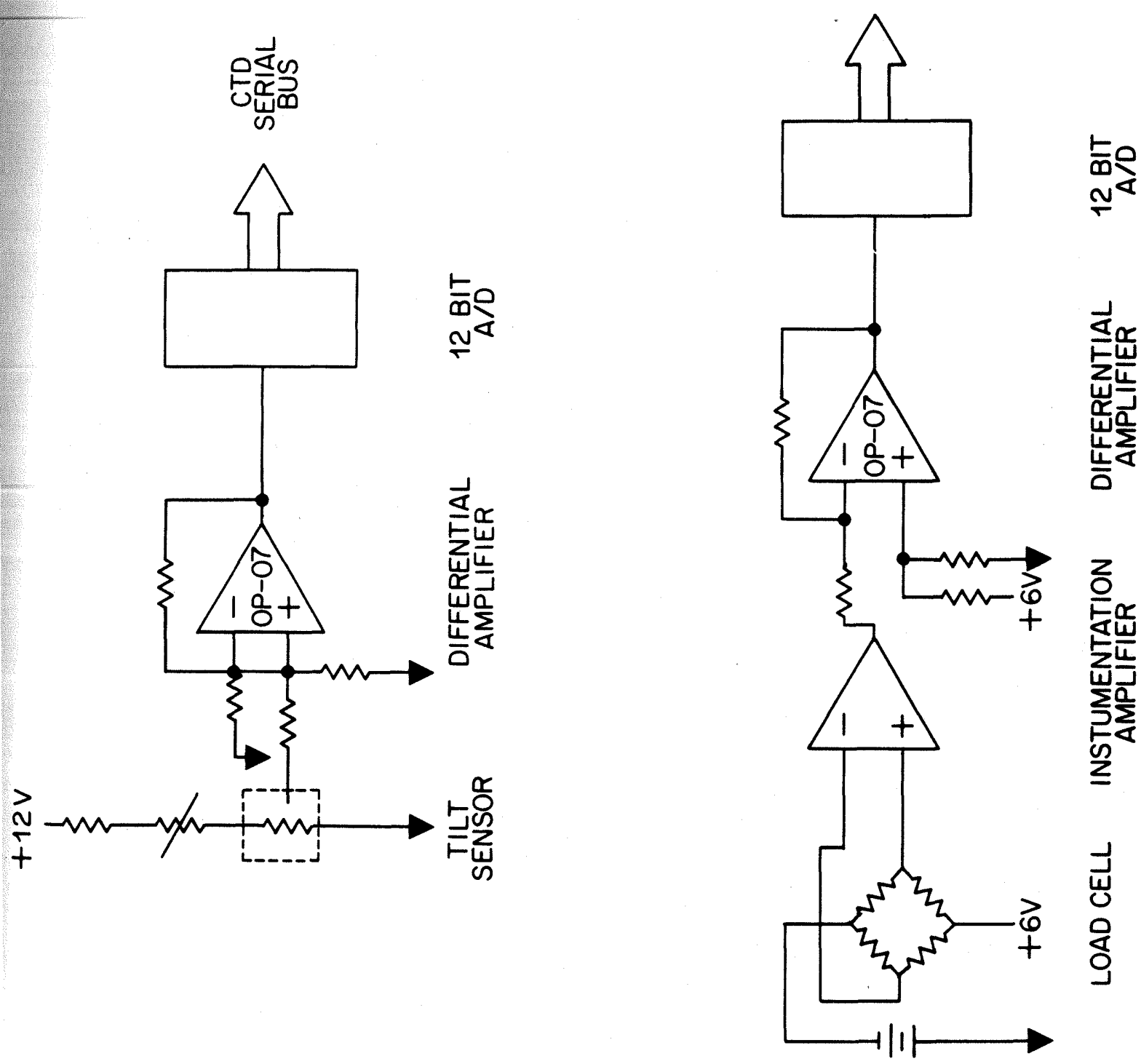
Al1 of the sensor outputs are digitized twenty-four times a second giving a temporal resolution of $41 \mathrm{msec}$. The data is organized in a serial data stream for transmission up the $E / M$ cable to a shipboard deck unit. The deck unit decodes the serial data for display and also supplies binary coded audio signals which are recorded by a standard audio tape recorder. The data can then be analyzed at a later time by replaying the audio tape.

\subsection{Procedure}

The specially instrumented CTD package was deployed at sea from the $R / V$ OCEANUS on two separate cruises. Both lowerings were done with the cable fed through a sheave attached to the A-frame on the fantail. The normal method of lowering is from the boom on the starboard side but because of operational limitations on these cruises the package was lowered in this manner. No other changes were made in the usual operating procedures. There was a major difference in sea conditions between the two cruises. The first cruise was during calm to moderate weather with small gentle ship motions. The second lowering was done about six hours after an intense winter storm with large sharp changes in pitch and roll angles. Both cruises were 150 miles south of Martha's Vineyard in the late fall/winter season.

\section{$12 / 14 / 81$ Cruise}

The weather as reported by the OCEANUS bridge was calm seas, wind southwest at 10 knots, ship pitch and rol1 less than $3^{\circ}$, increasing slightly after the CTD reached 1700 meters depth. The CTD package was attached to a standard .303 electromechanical cable wound on the ship's Markey winch. The package was lowered into the sea and halted at hull depth. It was then lowered at 25 meters per minute to 60 meters where its speed was increased to 40 meters per minute. At 228 meters depth 
the lowering speed was increased to 60 meters per minute and remained constant until the bottom of the cast at around 2000 meters depth. In order to simulate a normal CTD cast rosette bottles were fired at twenty different depths during its retrieval. At each bottle firing the CTD package was stopped for 15 to 20 seconds. Throughout the cast the data from the CTD, tension cell and tilt meters was monitored onboard the ship and recorded on an audio tape recorder.

\section{$1 / 6 / 82$ Cruise}

The sea conditions during this test were winds at 10 knots from the west, waves at 6 feet and swe11s also from the west. The CTD package was lowered into the water with a speed of twenty meters per minute to 172 . meters. The data from the tension cell stopped at 78 meters due to storm damage to the electrical harness. The pressure and tilt meters continued to operate. The CTD package was retrieved with 13 stops for rosette firings of the Niskin bottles. The data was again recorded on an audio tape recorder.

\subsection{Data Processing}

The audio tapes from the two lowerings were replayed at WHOI. The data was monitored by a CTD deck unit with a RS-232 serial data link with a Hewlett Packard 2113 computer. A11 of the data was transcribed onto a nine-track digital magnetic tape and once-a-minute listings were made of each of the CTD data channels.

Before and after each of the lowerings, the tilt sensors, tension cell and pressure transducer were calibrated. These calibrations were then used to determine connection factors for the raw data from the casts. The data processing software allows a linear correction to each of the data channels. This corrected data can then be displayed as listings and/or plots with the data converted into engineering units. The computer 
codes can display every data point or every nth point and also will average any number of observations. Any of the data channels can be plotted vs the others and/or time.

Initial data processing emphasized low-frequency events. Both orthogonal tilt angles and the tension were plotted as a function of time and of depth once every second. A listing of these data points was also made. From these plots areas of special interest for high-frequency events were identified. These areas were plotted on an expanded time scale once every 41 milliseconds. Plots of pressure vs time were done of both lowerings for every data point and used to determine velocities and accelerations.

\subsection{Sea Tests Results}

An analysis of the records of instrument package depth, cable tension, and package inclination was made to determine the package and cable behavior as they were lowered and retrieved through the water column.

Events of particular interest that this analysis could help detect and quantify included the following:

- Instantaneous rate of cable fall
- Instantaneous rate of CTD package fall
- Cable relaxation
- Cable snap loads
- Instrument tumbling and/or spinning.

Entire records were first examined. This first look was used to detect long period trends, to measure slow varying parameters - winch payout rates for example - to determine maxima and minima of tension and their rate of occurrence, and to identify record sequences of special interest. The time scale of these sequences was later expanded and the data studied in more detail. The results of this analysis are hereafter summarized. 
speed of cable fall. By differentiating the pressure record one obtains a record of instrument rate of travel in the vertical direction. On a down roll the cable can fall faster than the instrument and therefore down speed measurements cannot always be used to infer cable speed. On the other hand when the instrument is pulled upwards then cable and instrument travel together. If at that moment the winch is paying the cable out at a given rate then obviously the sheave must be going up at a speed equal to the sum of the payout rate and the rate of instrument climb. Now old salts would agree that in general a hard roll is followed by an equally hard down roll. Thus it seems fair to "expect" (in a statistical sense) the sheave to fall down as fast as it came up. The cable down speed would then be the down speed of the sheave augmented of course by the payout rate, or the cable's own terminal velocity whichever is the smaller. Applying this reasoning to the pressure data shown in Figure 9, the upward speed of instrument at time $t=8$ seconds is found to be $5.25 \mathrm{ft} / \mathrm{sec}$. The winch paying out at a rate of $2.4 \mathrm{ft} / \mathrm{sec}$, the sheave must be climbing at $7.65 \mathrm{ft} / \mathrm{sec}$. On the next down roll the cable will fall at $7.65+2.4=$ $10 \mathrm{ft} / \mathrm{sec}$. The pressure record shows the instrument to fall at that time $(t=10 \mathrm{sec})$ at $9.2 \mathrm{ft} / \mathrm{sec}$. The cable falling faster goes slack, as evidenced by the tension record. This example clearly shows that on occasions the cable can and indeed does fall faster than the instrument.

The maximum upward sheave speed observed in all records was found to be $11.58 \mathrm{ft} / \mathrm{sec}$. As further explained in Appendix 1, when the sheave fal1s at that rate, its speed then exceeds the instrument terminal velocity $(8.2 \mathrm{ft} / \mathrm{sec})$. It could also be equal to or larger than the estimated rate of cable free fall (12.2 ft/sec $\pm 1.2 \mathrm{ft} / \mathrm{sec})$. In these conditions, and with the winch secured, the cable could certainly be slack at its lower end and also most probably at its upper end. Paying cable out would 

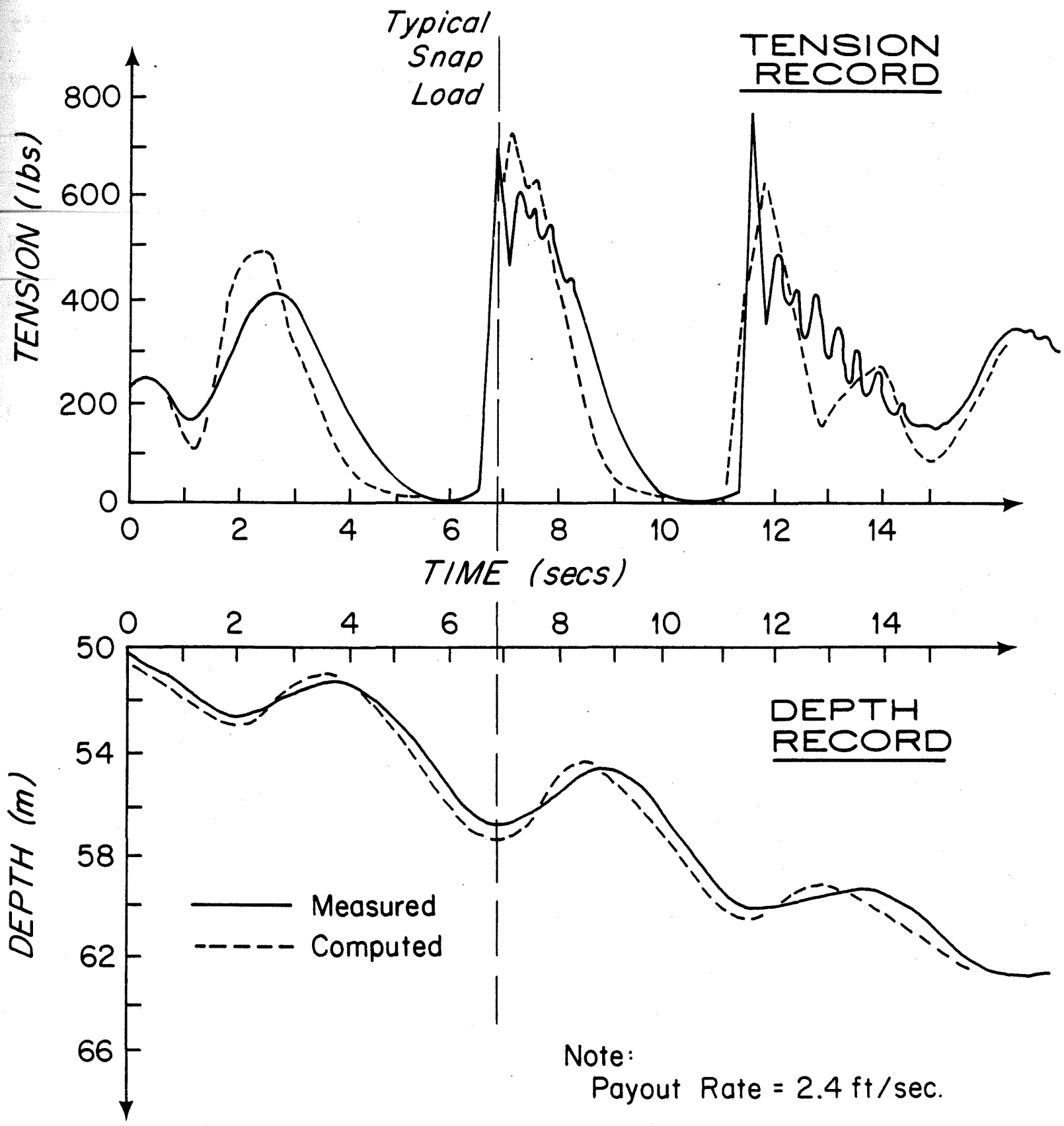

FIGURE 9. Records of tension and pressure measurements 
just increase the chances for cable relaxation at either or both ends.

Tension Measurements. Tension measurements, particularly those of the second lowering, revealed large deviations from the instrument immersed weight (306 1bs). Low levels of tension - including zero - were often encountered followed by values as high as three times the instrument weight. A typical dynamic section of the record was selected for detailed analysis. Figure 9, based on 24 data points per second, shows the synchronous measurements of cable tension and instrument depth as a function of time, starting from an arbitrary origin. This extremely interesting record illustrates cable relaxation followed by impact loading.

At time $t=4$ seconds the instrument starts to fall. The cable overrides the instrument 1.5 seconds later and the tension goes to zero $(t=5.5 \mathrm{sec})$. The cable remains slack for a second. At $t=6.5 \mathrm{sec}$ the instrument starts decelerating and is brought to zero speed $0.25 \mathrm{sec}$ later. The tension jumps from zero to 706 lbs over this short time interval. The snap load is followed by typical shock waves in the cable. As the instrument travels upwards the pull of the cable becomes less and less. Eventually the instrument stops climbing $(t=9 \mathrm{sec})$, starts to fall again acquiring terminal velocity at $t=10$ secs at which time the cable overrides the instrument again. A second relaxation takes place, followed by a second snap load $(t=11 \mathrm{sec})$.

Peak tensions reached in this particular series of events - 706 1bs or so - may seem deceivingly small when compared to the $7300 \mathrm{lbs}$ of cable strength. On the other hand more severe weather undoubtedly would have produced much larger peaks. Of more significance perhaps is that relaxation - which can permit kinks to form - happened repeatedly. Repeated snap loads would them be applied to a damaged cable. 
An attempt was made at reproducing the cable tension history using the mathematical model described in Appendix 2. As can be seen from Figure 9, predictions of cable relaxation followed by snap loads agree rather well with the measured values, despite model simplicity.

Tilt Measurements. The records indicated that the package was slightly tilted (5 to 6 degrees) and was turning slowly while being lowered and raised. The slow spin was probably caused by cable unlaying. Violent tumbling could not be observed.

\subsection{RECOMME NDATIONS}

Causes of lowering cable damage were identified and measured in situ. These include high stress levels at the head sheave, cable relaxation and snap loads. The flight pattern of typical CTD packages has been observed with the help of scale models. Math models were used to quantify tension levels, calculate terminal velocities and investigate instrument package stability. Based on this information the following recommendations to reduce or suppress the cause of cable damage and improve the package flight pattern are made.

\subsection{Modus Operandi}

As a first measure, limits should be set and observed as to maximum depth of casts and allowable winch speeds. To help plan safe lowerings, predictions of tension at the head sheave should be readily available. If, for example, one had graphs of peak tension versus cable length for different hauling speeds and sea states as shown in Figure 10, then the allowable cable length could be found from the intersection of the pertinent tension curve with the safe load (or the elastic limit) of a particular cable.

CTD lowering operations should certainly try to avoid slack cable conditions. Calculations of winch payout rates which would prevent the 


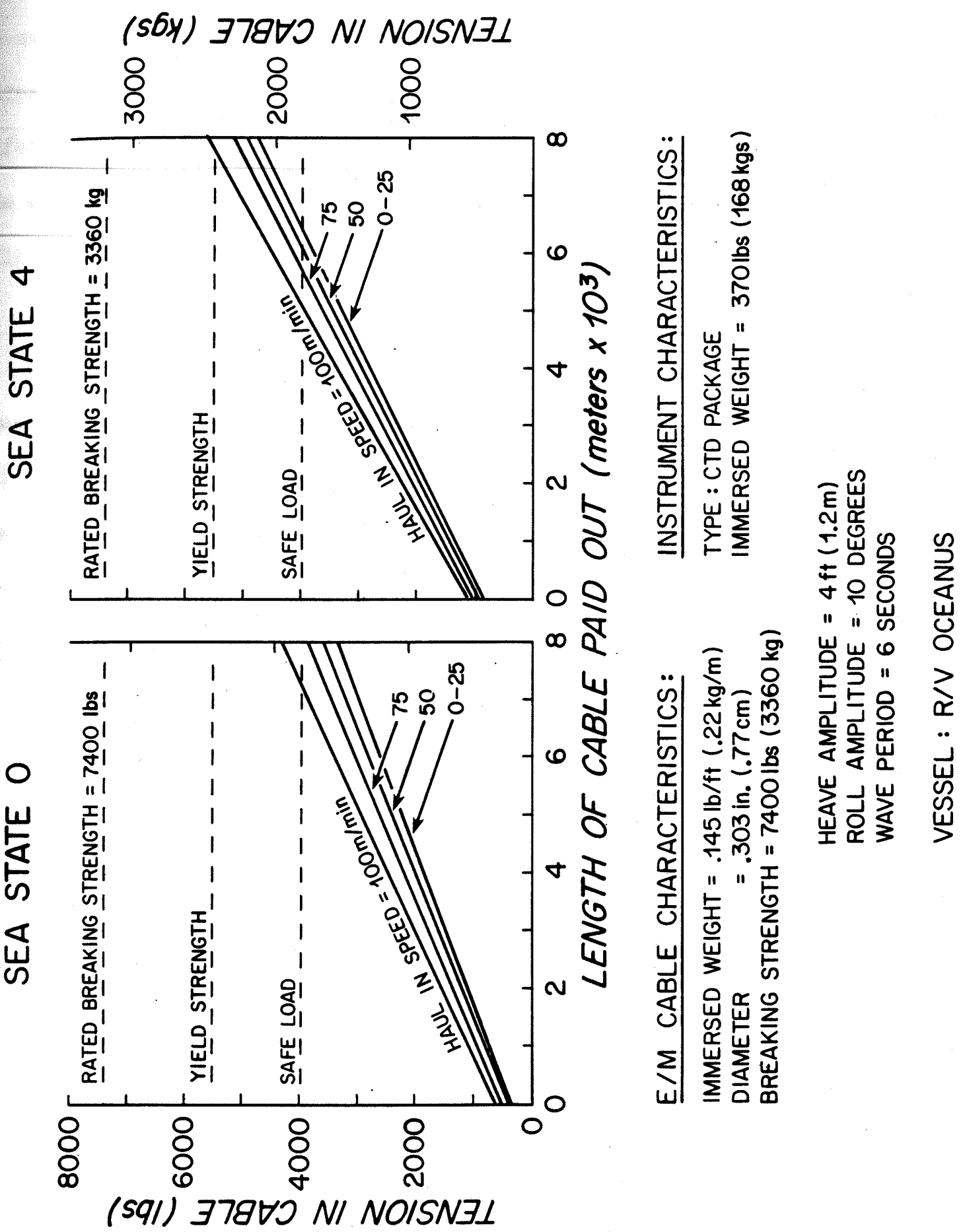

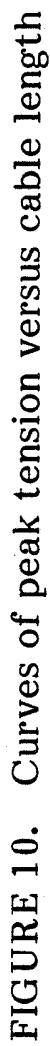


cable to become slack as a function of known (preferably measured) package terminal velocity and sea state should be made and presented in a friendly tabular or monograph form. Limits on payout rates should then be set accordingly. Examples are shown in Figure 11 of limits on payout rates for two different packages having terminal velocities of 8 and 12 $\mathrm{ft} / \mathrm{sec}$ respectively. It is apparent that every effort should be made to use a package which has as high a terminal velocity as the weight limits will a11ow.

\subsection{Improving CTD Packages}

Improving existing CTD packages can be achieved by decreasing the projected frontal area and increasing the weight by efficient ballasting. There are obviously limitations depending on the size and shape of the original package. If a large and heavy package exists, it may be difficult to increase its weight efficiently and still end up with one that can be practically managed at sea.

A package terminal velocity larger than the terminal velocity of the cable would certainly reduce the chances of cable slackness and kinking at the CTD end. In the cases studied here, that cable velocity is just over $12 \mathrm{ft} / \mathrm{sec}$. To achieve a velocity equal to or greater than this our standard CTD package was redesigned. The mounting frame was first removed to reduce drag. To compensate for the reduction in weight, ballast in the form of a lead collar was attached around the lower portion of the CTD instrument case. This further reduced drag by eliminating undesirable end cap effects caused by separate cylindrical instrument cases. The resulting smaller and faster package also accelerated more quickly as the plots in Figure 6 show. This efficient configuration can thus more readily react to dynamics caused by ship motions. 

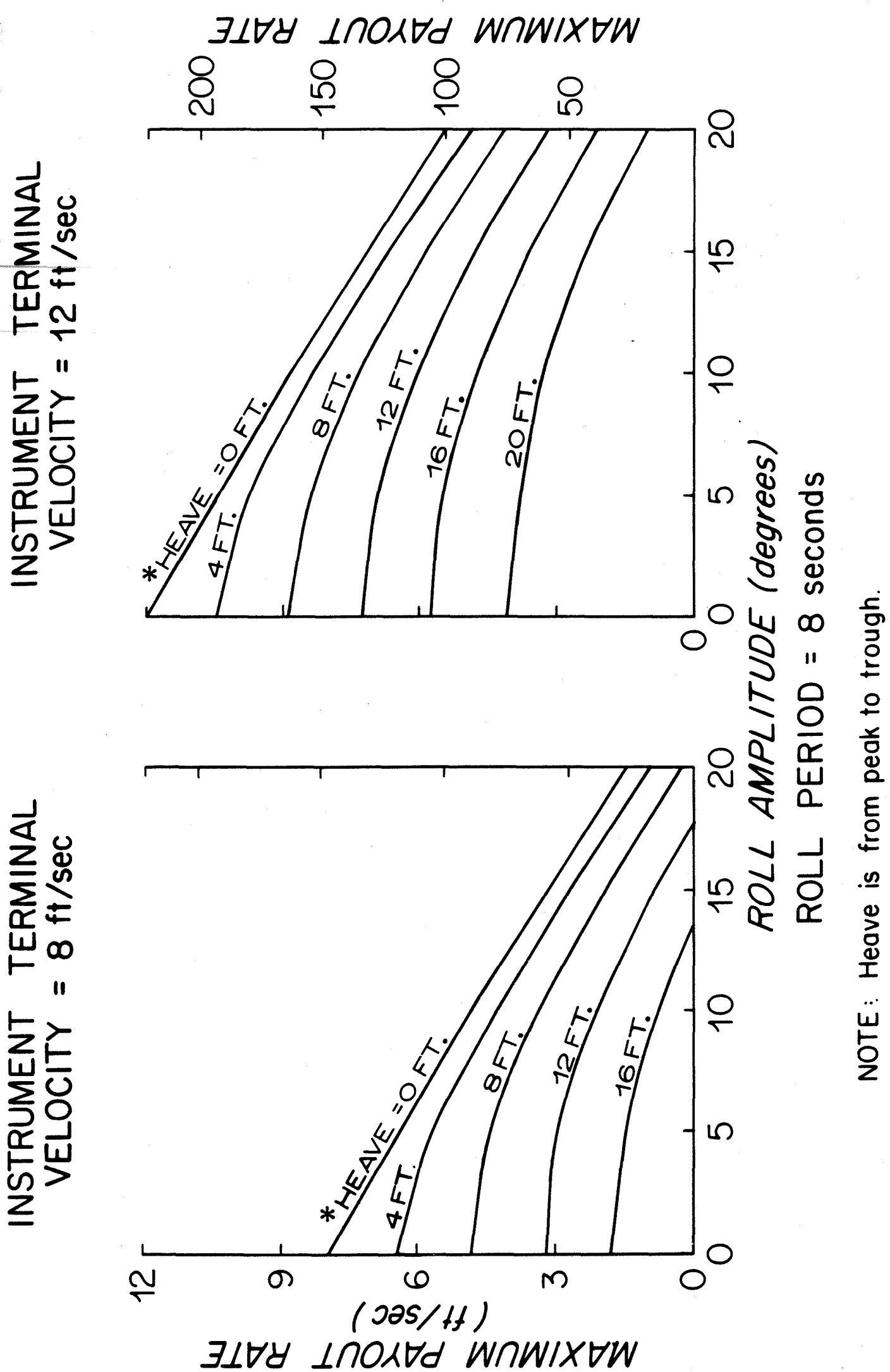

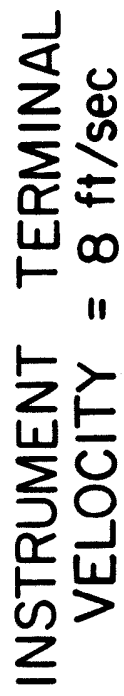

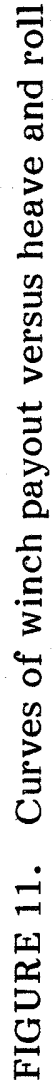


Static stability is important and can be best maintained by keeping instruments fairly long with heavy items low (ballast) and light, high drag items (bottles) high.

\subsection{Improving Lowering Equipment}

Setting limits on deployment depths to avoid high stresses at the sheave and on payout. rates to prevent cable slack conditions should be considered but temporary measures. Certainly the desirable goal remains the ability to perform deeper and faster casts in more severe weather conditions.

Ship motion produces high cable stresses, kinks, snap loads and often introduces deleterious effects on the quality of the data collected. Automatic motion compensation would help reduce or suppress these undesirable causes of system failure. Shock loads can be substantially reduced with the help of multiple sheave hydraulic or pneumatic accumulators. An active boom to suspend the head sheave can also be used. Another approach is to modulate the speed of the winch in response to measured sheave displacement rates. Accumulators and active booms are complex systems, they require ample deck space, and are stroke limited. For open ocean applications, the servo-controlled winch appears to be a more practical and attractive solution. A short discussion follows of the benefits introduced by winch speed regulation.

When hauling the cable and the instrument back on board ship in a rough sea way, the tension at the sheave is the instantaneous sum of the steady state load due to cable and instrument immersed weight and hauling drag and of the time varying load due to inertia and drag forces imparted on the cable and the instrument by the violent motion of the head sheave. These wave induced forces cause repeated high tension peaks. In this instance the instantaneous speed of ascent of the cable and instrument is 
the vector sum of the winch constant hauling speed and of the time dependent vertical component of the sheave speed. If the winch hauling speed could be made time dependent and regulated so as to produce a constant vector sum then the actual speed of cable and instrument ascent would be constant. Inertia effects resulting from speed changes would be suppressed as we11 as the substantial increase in drag forces due to upward sheave motion. The tension would be nearly constant, decreasing slowly as the cable is reeled in. High tension peaks due to dynamic loading would no longer be present. Deeper casts could be made in more severe weather conditions.

When lowering an instrument package in a rough sea way cable slackness followed by snap loads is likely to occur. Here again the actual cable lowering speed is the vector sum of the winch payout rate and of the vertical component of the head sheave speed. If the winch payout rate could be regulated to produce a constant vector sum smaller than the instrument terminal velocity then slack conditions, kinks, and snap loads would be entirely eliminated. Instruments could be lowered at much faster rates and in more severe weather, thus conserving precious ship time. A scheme to regulate winch speed is depicted in Figure 12. (Personal communication, J. G. Desureault, BIO, Canada, 1982).

To conclude, automatic motion compensation would greatly reduce the causes of failure identified in this study. By enabling casts to be made in larger depths and more severe weather it would put costly ship time to better use. By providing smooth lowering and vertical station keeping capability it would enhance data quality and expand the scope of scientific experiments using profiling instrumentation techniques.

The need to improve and upgrade present oceanographic winches has been fully recognized and motion compensation systems best suited 


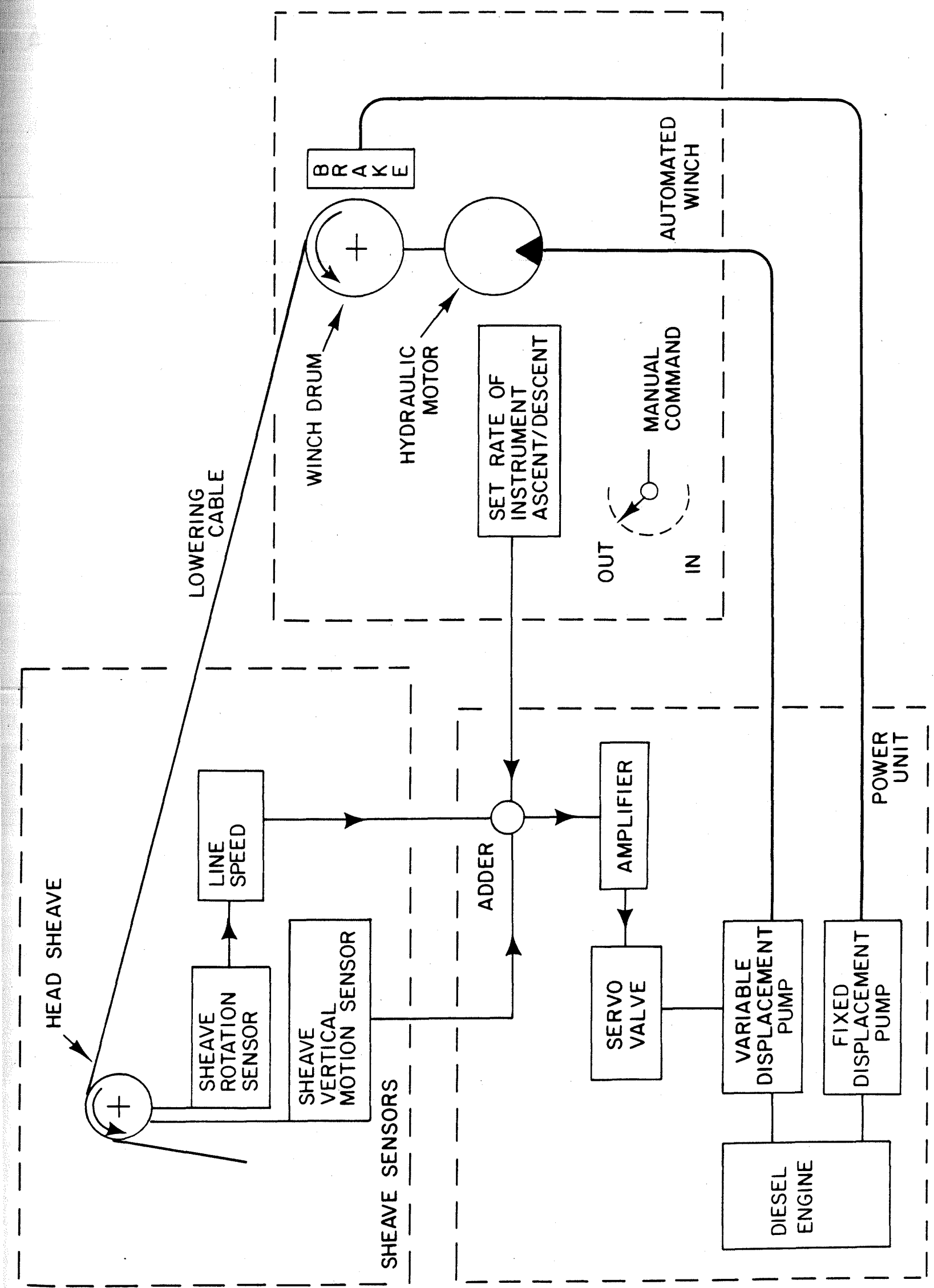

O 
APPENDIX 1. Maximum Sheave Speed and Estimated Terminal Velocity of CTD Cable

1. Maximum Sheave Speed

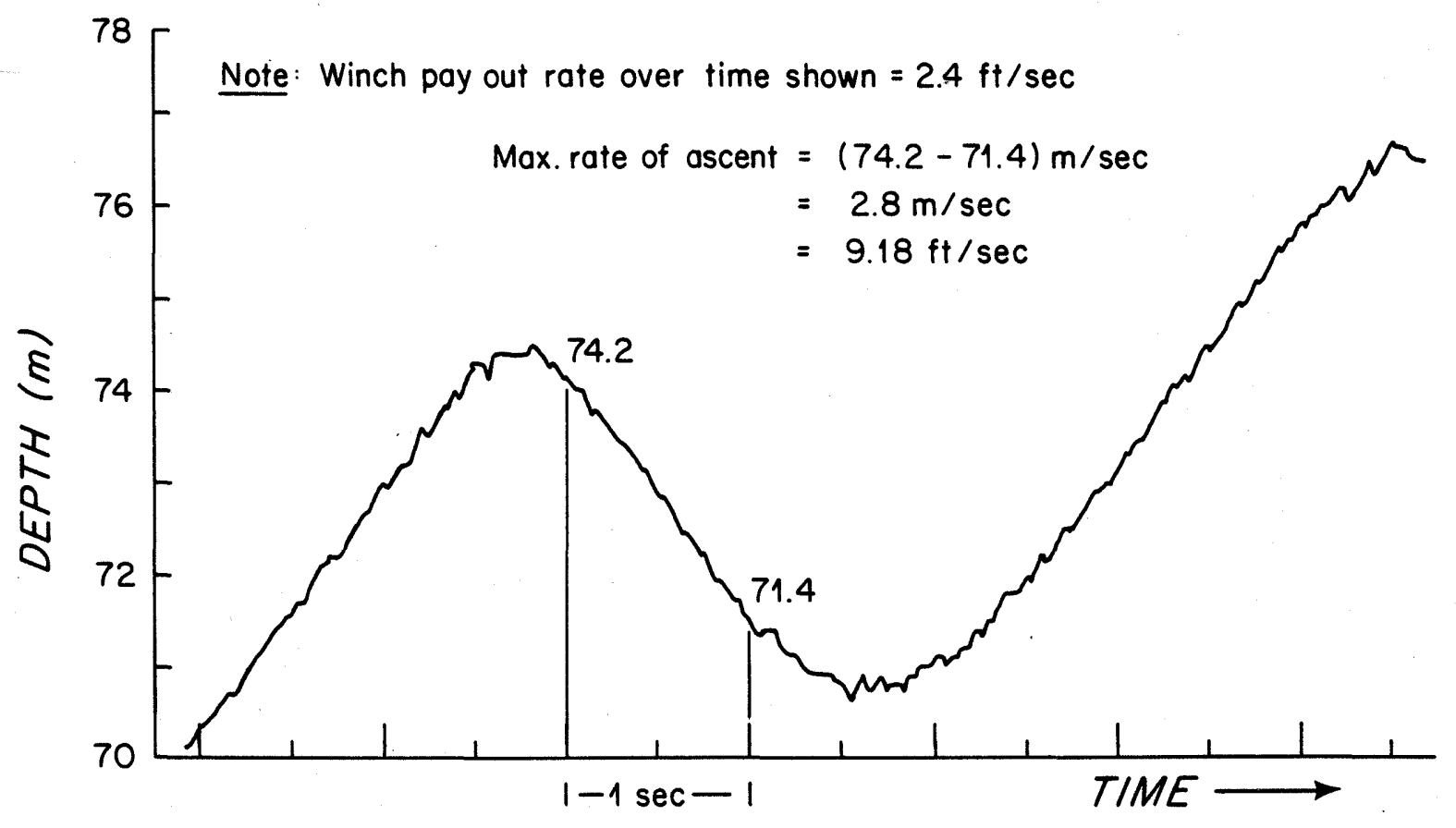

Figure 13

The section of the CTD depth record with the largest recorded rate of instrument ascent is shown in Figure 13 above. From this record, the rate is found to be $2.8 \mathrm{~m} / \mathrm{sec}$ or $9.18 \mathrm{ft} / \mathrm{sec}$. Adding $2.4 \mathrm{ft} / \mathrm{sec}$ for the payout rate at the time yields a measured sheave upward speed of $11.58 \mathrm{ft} / \mathrm{sec}$. 
Cable Terminal Velocity

The highest possible cable free fall velocity is achieved when the cable has a minimum drag-to-weight ratio. This obviously is obtained when the cable falls vertically.

Let us consider a length of cable L falling vertically. At terminal velocity $V_{T}$, the gravity pull equals the cable drag. This condition can be expressed by:

where

$$
W_{L}=\frac{1}{2} \rho C_{D r} D L V_{T}^{2}
$$

$$
\begin{aligned}
W_{L} & =\text { Cable immersed unit weight }(1 \mathrm{~b} / \mathrm{dt}) \\
P & =\text { Sea water mass density }=2 \text { slugs/cu.ft } \\
D & =\text { Cable diameter (ft) } \\
C_{D T} & =\text { Cable longitudinal drag coefficient. }
\end{aligned}
$$

From this equality the terminal velocity is:

$$
V_{T}=\sqrt{\frac{W_{L}}{C_{D_{T} D}}}
$$

Using values of

$$
\begin{aligned}
& D=0.303 \text { in } \quad \text { (CTD cable specs) } \\
& W_{L}=0.116 \mathrm{lb} / \mathrm{dt} \quad \text { (CTD cable specs) } \\
& C_{D_{T}}=.012 \text { (high) and } .008 \text { (low) }
\end{aligned}
$$

yields

High terminal velocity $\quad=13.52 \mathrm{ft} / \mathrm{sec}=(4.03 \mathrm{~m} / \mathrm{sec})$

Low terminal velocity $\quad=11.03 \mathrm{ft} / \mathrm{sec}=(3.36 \mathrm{~m} / \mathrm{sec})$

Average terminal velocity $=12.27 \mathrm{ft} / \mathrm{sec}=(3.70 \mathrm{~m} / \mathrm{sec})$

Thus the estimated speed of maximum cable free fall is
$12.27 \mathrm{ft} / \mathrm{sec}$
$( \pm 1.25 \mathrm{ft} / \mathrm{sec})$
or $\quad 3.74 \mathrm{~m} . \mathrm{sec}$
$( \pm 0.34 \mathrm{~m} / \mathrm{sec})$
or $224 \mathrm{~m} / \mathrm{min}$
$( \pm 20 \mathrm{~m} / \mathrm{min})$ 
for the need are being studied.

A last remark should be made to emphasize once more the importance of good cable handling practices. A wealth of information on this critical subject can be found in the recently published Handbook on Oceanographic Winch, Wire and Cable Technology (Reference 4). 
6.0 REFERENCES

1. H. O. Berteaux, R. G. Walden, D. A. Moller, Y. C. Agrawal, "A Study of CTD Cables and Lowering Systems", WHOI Technical Report 79-81 (December 1979).

2. M. F. Cook, "Hydrodynamics of CTD Instrument Packages", WHOI Technica1 Report 81-76 (September 1981).

3. H. O. Berteaux and R. G. Walden, "CTD Lowering Mechanics", Deep Sea Research (1983).

4. A. Driscoll, Editor, "Handbook of Oceanographic Winch, Wire and Cable Technology" (1983).

5. J. E. Goeller and P. A. Laura, "A Theoretical and Experimental Investigation of Impact Loads in Stranded Stee1 Cables", The Catholic University of America, Department of Mechanical Engineering, Report 70-2 (1970). 


\section{APPENDIX 2. Mathematical Model of CTD Package Dynamics}

In the course of the CTD study reported herein an attempt was made at developing and exercising a simple computer model which could predict the occurrrence of cable relaxation followed by snap loads.

Following the approach described in Reference 5, the single degree of freedom system shown in Figure 14 is used to represent the package and lowering cable. In this model the following assumptions are made:

- The motion of the package is entirely vertical.

- The mass of the cable is assumed to be a small fraction of the equipment mass. This would be the case for rather short lengths of cable (hundreds of meters instead of thousands), or if the cable is light (Kevlar line for example), or if the payload entrains a lot of water.

- The cable is treated as an elastic spring which changes its length as the winch pays the cable out or reels it in. In the elastic range of cable elongation the spring constant $k$ is given by

$$
K=\frac{E \Delta}{L}
$$

where $E$ is the cable modulus of elasticity (psi)

$$
\begin{aligned}
& A \text { is the cable metallic area (sq/in) } \\
& L \text { is the cable length (ft). } \\
& K \text { will then be expressed in lbs.ft, }
\end{aligned}
$$

- Equipment drag is nonlinear and of the form

$$
D=\frac{1}{2} C_{p} \Delta_{p} V|V|
$$

- Equipment drag is assumed much larger than the cable drag.

The cable upper end $\left(X_{1}(t)\right)$ is forced to follow a prescribed displacement such as a sinusoidal or a known time series. The ensuing displacement of the CID package $\left(X_{2}(t)\right)$ is found by numerical integration 

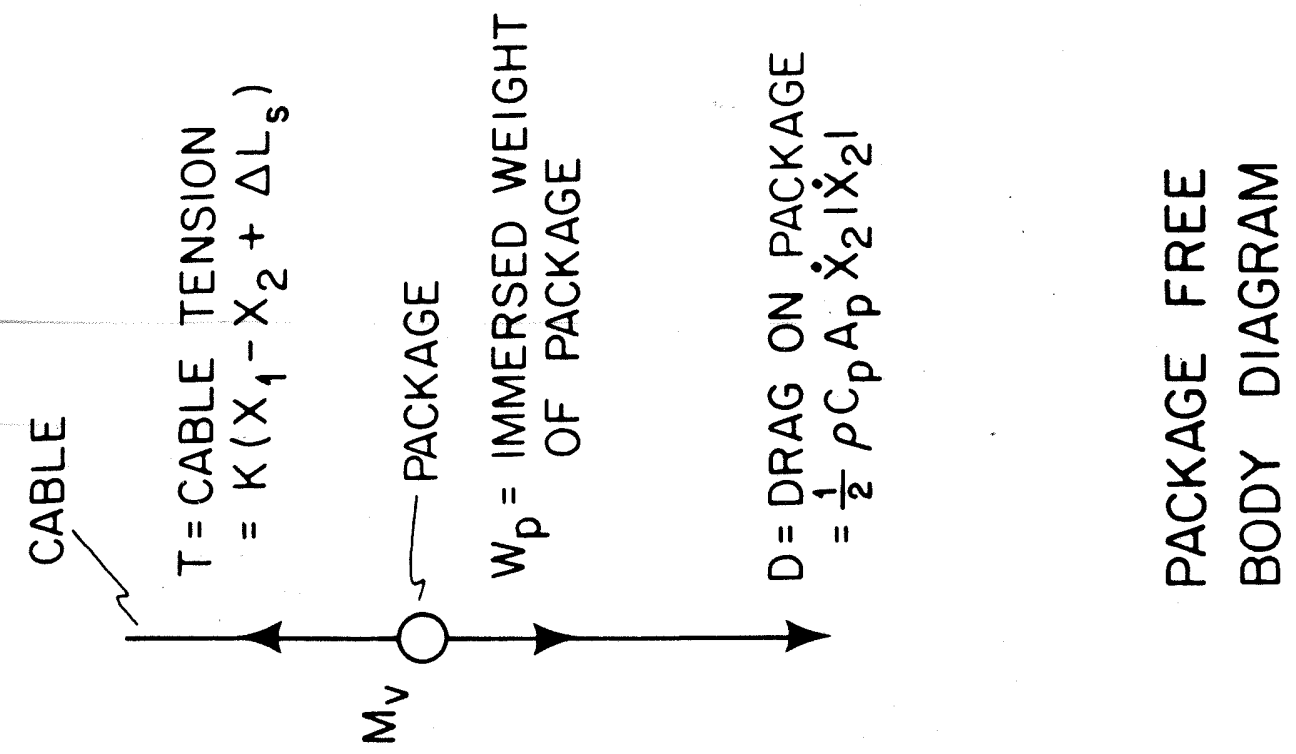

$\sum_{u}$
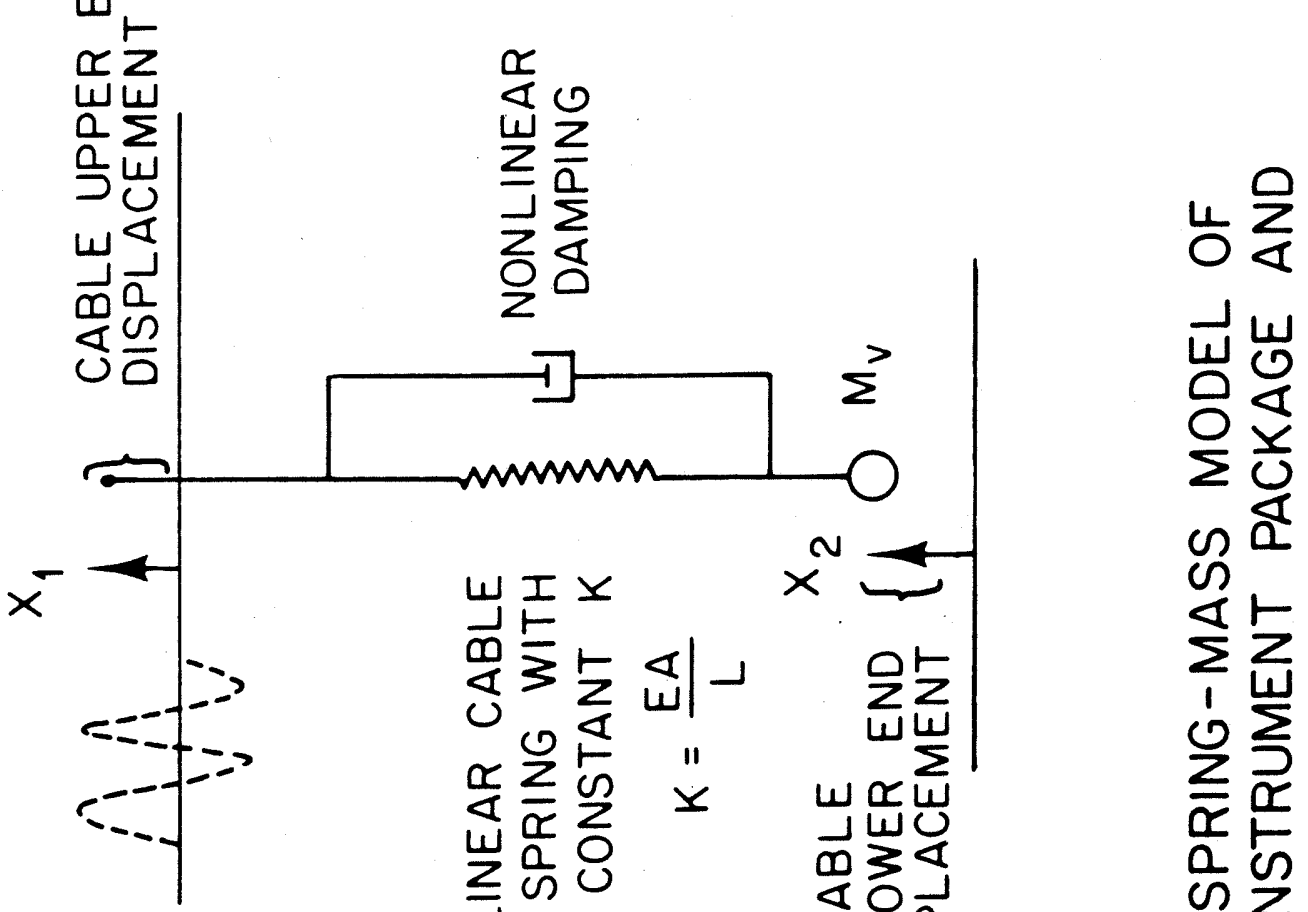

لس

0

innm 10

$0<\infty$

$\sum \frac{1}{0} \leqslant$

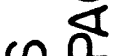

$\circlearrowleft$ a

W $I$

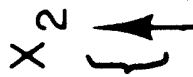

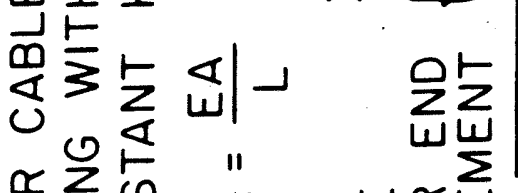

$\approx \sum \frac{z}{\alpha} \sum_{0}^{\prime \prime} \quad w \propto \sum$

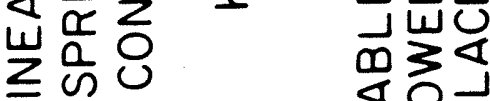

$\mathbb{U}_{0} \frac{1}{0}$ 
of the instrument equation of motion, namely:

$$
K\left(x_{1}-x_{2}\right)-\frac{1}{2} p c_{p} \Delta_{p} \dot{x}_{2}\left|\dot{x}_{2}\right|=m_{v} \ddot{x}_{2}
$$

where

$$
\begin{aligned}
& e_{p} \text { is the sea water mass density (slug/cu.ft) } \\
& C_{p} \text { is the drag coefficient of the package } \\
& A_{p} \text { is the cross section area of the package normal } \\
& \text { to the direction of travel (sq.ft) } \\
& \dot{x}_{2} \text { is the speed of package travel (ft/sec) } \\
& \ddot{x}_{2} \text { is the package acceleration } \\
& m_{\checkmark} \text { is the package virtual mass. }
\end{aligned}
$$

The instantaneous cable tension at the instrument is in turn found from

$$
\begin{gathered}
T(s, t)=W_{p}+K\left(x_{1}-x_{2}\right) \\
W_{p} \text { being the package immersed weight }
\end{gathered}
$$

When the tension $T(s, t)$ goes to zero, the motion of the instrument is governed by the "free flight" equation:

$$
-W_{p}-\frac{1}{2} \rho c_{p} \Delta_{p} \dot{x}_{2}\left|\dot{x}_{2}\right|=m_{v} \ddot{x}_{2}
$$

When the tension becomes positive, Equation (2.1) prevails again. Speed and displacements used when switching from one equation to the other are of course those computed at the time immediately preceding the switch over.

A FORTRAN computer program (CTDDOWN) was written (see listing at end of this Appendix) to numerically integrate the equation of motion. Typical program input includes type of surface displacement prescribed, payout rates, cable characteristics and instrument package characteristics. Typical program output includes a summary of the input data, and a listing of head sheave displacement and speed, of package depth and speed, and of cable tension as a function of time. 
Page 3 of A.2

This computer program was used to investigate the behavior of typical CTD packages when deployed from a rolling and heaving ship of known geometry. Using a suitable time series of sheave displacement, values of cable tension and CID depth were computed and compared against actual measurements. When using a spring constant $K$ as previously defined, the tensions predicted were found to be larger than those recorded. However reducing the stiffness of the theoretical constant did produce the reasonable predictions shown in Figure 9. 
\$ TYPE CTINOWN,FOR;28

CTIIIOWN PROGRAM. THIS PROGRAM COMFUTES THE INSTANTANEOUS IIEPTH ANI SFEEII OF A CTII INSTRUMENT PACKAGE BEING LOWEFEII FORIM A ROLLING SHIF. THE TENSION AT THE CABLE CTII ENII IS ALSO COMFUTEI.

FROGRAM WFITTEN EY H.O. BERTEAUX, JUNE 11983

PROGRAM REQUIREN INPUT INCLUIES:

SFECIFICATION OF SUFFACE EXCITATION

CHARACTERISTICS OF LOWERING CABLE, ANI LOWEREN PACKAGE

INITIAL CONIITTIONS

NON EXECUTABLE STATEMENTS

CHAFACTER*5O FILENAME, CARLLENAME, INSTRUMENT, SHIFNAME, IIATE

DIIMENSTON SHEAUE(1000), TIMIIAT (1000)

INFUT STATEMENTS

IIIENTIFIES SHIF ANI IIATE

WRITE $(6, *)$ 'NAME OF SHIF?'

REAII $(5,1000)$ SHIFNAME

FORMAT $(A)$

WRITE $(\sigma, *)$ 'IIATE?'

REAI $(5,1000)$ RIATE

SPECIFIES SURFACE EXCITATION

WRITE $(\sigma, *)$ 'IS SHEAUE IISFLACEMENT SFECIFIEI IN IIATA FILE?'

U!RITE $(6, *)$ 'IF YES ENTER $1 \ldots$... IF NO ENTEF 0 '

REAII $(5, *)$ ANSWER

IF (ANSWEF,EQ, 1) THEN

GO TO 200

ELSE

GO TO 100

ENII IF

WRITE $(b, *)$ 'SHEAVE IITSPLACEMENT IS ASSUMEU TO BE PERIOIIC' WFITE $(6, *)$ 'ENTER HEAVE AMFLITUIE (FT)'

REAII $(5, *)$ HEAVA

WRITE $(6, *)$ 'ENTEF ROLL AMPLITUUE (IIEGREES) ANI PERIOI(SECS)'

REAII $(5, *)$ FOLLA, FOLLLT

WRITE $(6, *)$ 'ENTER HORIZONTAL ANI VERTICAL IIISTANCE TO SHEAUE(FT)'

FEATI $(5, *)$ XSHEAUE, YSHEAVE

WRITE $(\sigma, *)$ 'ENTER COMPUTATION TIME INCREMENT(SECS)'

REAI $(5, *)$ TINC

GO TO 400

WRITE $(6, *)$ 'NAME OF IIATA FILE?'

REAII $(5,1000)$ FILENAME

WRITE $(6, *)$ 'ENTER TIME SPAN ANI TIME INTERUAL RETWEEN IIATA FOINTS' REATI $(5 * *)$ TSFAN, TIIATA

UIRITE $(6, *)$ 'ENTER COMPUTATION TIME INCREMENT'

FEALI $(5, *)$ TINC

WFITE $(6, *)$ 'ENTER HORIZONTAL ANI UERTICAL DISTANCE

$\$$ TO SHEAVE (FT),

READ $(5, *)$ XSHEAUE, YSHEAVE 
Page 5 of A.2

IFOINTS $=($ TSFAN/TIIATA $)+1$

OFEN (UNIT=1, FILE=F ILENAME, STATUS=' OLII', FEARIONLY)

I10 $300 \quad I=1$, IFOINTS

REAI ( 1, *) TIMIAT (I), SHEAVE (I)

SHEAVE $(I)=$ SHEAUE $(I) * 3.281$

CONTINUE

ENI OF SURFACE EXCITATION INFUT

NOW ENTERS INSTRUMENT PACKAGE CHARACTEFISTICS

WRITE $(6, *)$ 'ENTER CTII CHARACTERTSTICS'

WFITE $(6, *)$ 'ENTER INSTFUMENT NAME'

REAII $(5,1000)$ INSTRUMENT

WRITE $(6, *)$ 'ENTEF CTI UIFTUAI. MASS(SLUGS) ANII CTI IMIERSEI WEIGHT(IES)'

REAII $(5, *)$ UMASS, WETW

UFITE $(6, *)$ 'ENTER CTII IIRAG CONSTANT (CI*A,SQ-FT)'

FIEAII $(5, *)$ IIFAGC

NOW ENTERS CAELE CHARACTERISTICS

WRITE $(6, *)$ 'ENTEF' CABLE CHARACTEFISTSICS'

WFITE $(6, *)$ 'ENTEF CAELE NAME'

REAII $(5,1000)$ CABLENAME

WFITE $(\sigma, *)$ 'ENTER CAFLE ELASTIC CONSTSANT (E*A)'

REAII $(5, *)$ ELASTC

NOW ENTERS INITIAL CONIITIONS

WIFITE $(6, *)$ 'ENTER INITIAL. CONIITIONS'

WFITE $(6, *)$ 'ENTER CTI IIEFTH(M) ANI CTII SFEEI(M/SEC) AT TIME ZEFO'

REAII $(5, *)$ TZII, TZU

WRITE $(6, *)$ 'ENTEF CAELE TENSION(LB) ANI FAYOUT RATE(M/MIN) AT TIME ZERO'

REAII $(5, *)$ TZTEN, TZFOUR

ENI OF INPUT IIATA

WRITE $(6, *)$ '***** ENI OF INPUT IIATA $* * * * * *$ '

NOW FRINTS A SUMMAFIY OF INFUT IIATA

WFITE $(6,1010)$

FORMAT $(/ / 1,1.0 X$, SUMMARY OF INFUT IIATA', $/ / 1)$

WFITE $(6,1015)$ IIATE

FOFIMAT $(2 X, '$ IIATE', $2 X, A 2 O, / 1)$

WFITE $(6,1020)$ SHIFNAME

FORMAT (2X, 'SHIF' NAME:', $2 X, A 20, / / 1)$.

IF (ANSWEF, EQ.1) GO TO 550

WFITE $(6, *)$ 'SHEAUE IIISFLACEMENT IS ASSUMEII TO BE FERIOUIC'

WRITE $(6,1025)$ HEAUA

1025

FORMAT (?X, 'AMPLITUIIE OF HEAUE $=\prime, 1 X, F 4,1,1 X, '(F T) '$ )

WFITE $(6,1030)$ ROLLA

FOFIMAT (2X,' AMFLITUIIE OF FOLLL=', $1 X, F 4,1,1 X, '($ IEGREES)')

WFITE $(6,1035)$ FOLLT

FOFMAT (2X, 'FEFTTOR=', $\left.1 X, F 4,1,1 X,{ }^{\prime}(S E C) \prime\right)$

CONT INUE

UIRITE $(6,1.040)$ XSHEAVE

1040

FOFMAT $2 X$, 'HOFIZONTAL IIISTANCE FFOM SHIF $F$.L.

$\$$ TO SHEAVE $\left.=\prime, 1 X, F 6,2,1 X,{ }^{\prime}(F T)^{\prime}\right)$ 
WFITE $(6,1045)$ YSHEAVE

FOFMAT (2X, 'UERTICAL IISTANCE FFIOM SHIF W.L.

\$ TO SHEAUE $=,, 1 X, F 6,2,1 X,(F T),, 1 / 1)$

IF (ANSWER +ER. O) GO TO 600

WFITE 6,1050$)$ FILENAME

FOFMAT ( $2 X$ 'SHEAUE IIISPLACEMENT AS SPECIFIEII IN FILE', $1 X, A 50, / / /$ )

NOW FFINTS CABLE IIATA

UIFITE $(6,1052)$

FOFIMAT ( $2 X$, 'CAELE CHAFACTEFISTICS',/)

WFITE $(6,1055)$ CABLENAME

1055

FOFMAT (2X,'CAELE NAME:', $2 X, A 20)$

WRITE $(6,1060)$ ELASTC

FOFMAT (2X, 'CABLE ELASTIC CONSTANT $=$ ', $1 X, F 9,0,1 / 1$ )

NOW PRINTS CTI CHAFACTEFISTICS

WFITE $(6,1062)$

1062 FOFMAT (2X, 'CTI CHAFACTEFISTICS', 1$)$

WFITE $(6,1065)$ INSTRUMENT

1065

FOFMAT ( $2 X, '$ INSTRUMENT NAME:', $2 X, A 2 O)$

WFITE $(6,1070)$ UMASS

1070

FOFMAT ( $2 X, ' C T I I$ UIRTUAL MASS $=\prime, 1 X, F 7,2,1 X, '(S L U G S) '$ )

WRITE $(6,1075)$ WETW

1075

FORMAT (2X, 'CTI WEIGHT IN WATER', $1 X, F 7,2,1 X, '(L E S) '$ ')

WFITE $(6,1080)$ IIFAGC

FORMAT (2X,'CTII LIRAG CONSTANT=', 1X,F6.2,1X,'(SR-FT)',//1)

NOW PRINTS CONDITIONS AT TIME ZEFO

WFITE ( 6,1082$)$

1082 FOFMAT (2X, 'INITIAL CONOITIONS', /)

WFITE (6,1085) TZI

1085 FORMAT (2X,'CTD INITIAL IIEPTH=', $\left.1 X, F 8,2,1 X, '(M)^{\prime}\right)$

WFITE $(6,1090)$ TZU

1090 FDFMAT $\left(2 X,{ }^{\prime}\right.$ CTII INTTIAL SFEEII=',1X,F6,2,1X,'(M/SEC)')

WFITE (6,1095) TZTEN

1095 FOFMAT $(2 X$, 'CAELE INITIAL TENSION=', 1X,F8,2,1X,'(LFS)')

WFITE 6,1100$)$ TZFOUF

1100 FOFMAT $(2 X$, 'CABLE FAYOUT FIATE $=\prime, 1 X, F 6,2,1 X, '(M / M T N),, / / /)$

NOW PRINTS HEATINGS OF COMPUTATIONS RESULTS

WFITE $(6,1105)$

FORMAT (24X,' COMFUTATION RESULTS', /1)

WRITE $(6,1110)$

1110

FORMAT $\{2 X, '$ TIME', $3 X$, 'SHEAUE', $6 X, '$ CTII TIEFTH', $4 X$,

\$ 'CTII SPEEI', $2 X$,'CTI ACCEL.',3X,'CAELE TENSION') WFITE $(6,11.15)$ FORMAT $(2 X, '($ SEC)', 2X,'(FEET)', 3X,'(FEET)', 3X,'(METER)',

$\left.\left.\$ 2 X, '(F T / S E C)^{\prime}, 2 X\right)^{\prime}(F T / S E C-S Q)^{\prime}, 6 X, '(L E S)^{\prime}, / 1\right)$

NOW PROCEEIIS WITH ANALYSTS OF CTII EEHAUIOF

IF (ANSWER +EQ.1) GO TO 2000

COMFUTES CTII RESF'ONSE TO FEFIOUIC EXCITATION

PFELIMINAFY COMFUTATIONS

COMFUTES INITIAL SFFING CONSTANT

CONUERTS FOLL AMFLITURE FROM IIEGREES TO RAIIIANS 
FOLLA $=$ FIOLLA*3.1416/180.0

FAIIIUS=S(RFT ( $X S H E A U E * * 2+Y S H E A U E * * 2)$

BETHA=ATAN (YSHEAUE/XSHEAVE)

SUFFX $=$ FIAIIIUS*SIN (EETHA) - HEAUA

IIEFTH $=-$ TZII*3.281

SFFING $=E L A S T C /(S U F F X-$ IIEF'TH $)$

COMFUTES UNSTRECHEI LENGTH OF CTII CARLE

FELAXL =SUFFX-IIEF'TH-TZTEN/SFFING

COMFUTES INITIAL CTD SFEFI

FAYOUT $=-3.281 *$ TZFOUF $/ 60.0$

SFEEII $=$ TZU*3.281

TENSION=TZTEN

COMFUTES INITIAL CTI ACCELERATION

ACCEL $=$ (TENSIDN-WETW-IIFIAGC*SFEEII*AES (SFEEII)) /UMASS

IF (ABS (ACCEL) . LE. 0.01$)$ ACCEL $=0.0$

TIME $=0.0$

CALL RESULTS (TIME, SUFFX, IIEPTH, SFEEI, ACCEL, TENSION)

STARTS INTEGRATION FROCESS

$k=1$

CONTINUE

TIME $=K * T I N C$

IF (TIME.GT . ROLLT) 90 TO 5000

OLISUURF $X=S U F F$

OLIIIEFFTH=LIEF'TH

SUFFX $=-H E A U A * \operatorname{COS}(2.0 * 3.1416 * T$ IME/FOLLT $)+F A I I U S *$

\$ SIN(EETHATFOLLA*SIN(2.0*3.1416*TIME/FOLLT))

CALL INTEGFATION ELASTC, FELAXL, FAYOUT, TIME, SPEEI,

\$ ACCEL, TINC, TIEPTH, SUFFX, OLIISURFX, OLIIIEPTH, TENSION,

* INETW, IIFAGC, UMASS)

CALL RESULTS(TIME, SUFFX, MIEFTH, SFEEI, ACCEL, TENSION)

$K=K+1$

GO TO 1500

PROGRAM COMFUTES CTI RESFONSE TO SPECIFIEI SHEAUE IIISFLACEMENT

FFELIMINARY COMPUTATIONS

COMFUTES INITIAL CAELE SFFING CONSTANT (SFRING)

FALIIUS $=\$$ SRTT ( XSHEAUE* $* 2+Y$ SHEAUE**2)

EETHA =ATAN (YSHEAVE/XSHEAVE)

SUFFX $=$ SHEAUE $(1)+$ RAIITUS $* S I N($ HETHA $)$

IIEF TH $=-T Z I I * 3.281$

SPFING=ELASTC/(SURFX-XEPTH)

COMFUTES UNSTFETCHEU LENGTH OF CTII CAELE

FELAXL = SUFFX-TIEFTH-TZTEN/SFFING

COMFUTES INITIAI CTII SPEEI

SFEEII $=T Z Y * 3.281$

TENSION=TZTEN

COMFUTES INITIAL CTI ACCELEFATION 


\section{Page 8 of A.2}

ACCEL_= (TENSION-WETW-IIRAGC*SFEEII*ABS (SPEEI)) /UMASS TIME $=0.0$

CAI.L FIESULTS(TIME, SURFX, IIEFTH, SFEEI, ACCEL, TENSION) COMFUTES FAYOUTKATE

FAYQUT $=-3+281 *$ TZPOUFI 60.0

STAFTS INTEGRATION PROCESS

$K=1$

$M=2$

2100 CONT INUE

TIME $=K$ KT INC

IF (TIME,GT, TSFAN) GO TO 5000

OLIISUFF $X=$ SURFX

OLIIIIEPTH=IIEFTH

C.ALL IIATASHEAUE (M, TIMLIAT, SHEAUE, TIME, SURFX, TINC, TIATA)

CALL INTEGRATION (ELASTC, FELAXL, FAYOUT, TIME, SFEEII, ACCEL, \$ TINC, IIEFTH, SUFFX, OLIISUFFX, OLIIUEF'TH, TENSION, WETW, IIFAGC, \% UMASS)

c

CALL RESULTS (TIME, SURFX, IIEPTH, SFEEI, ACCEL, TENSION)

$K=K+1$

GO TO 2100

STOP

ENI

SUBROUTINE TIATASHEAUE (M, TIMIIAT, SHEAUE, TIME, SURFX, TINC, \$ tIIATA)

THIS SURFOUTINE COMPUTES THE SHEAVE POSITION (SURFX) FOR EACH TIME INCREMENT BY LINEAR INTERFOLATION BETWEEN GIVEN SHEAUE IITSFLACEMENT IIATA POINTS

IIMENSION TIMIIAT(1000), SHEAVE(1000)

IF (TIME.GT.TIMIIAT (M)) GO TO 3100

3000 SURFX $=$ SURFX+(SHEAUE (M) -SHEAVE $(M-1)) * T I N C / T$ TIATA GO TO 3200

$3100 \quad M=M+1$

GO TO 3000

3200 RETURN

ENII

SUEFOUTINE INTEGRATION ELASTC, RELAXL, F'AYOUT, TIME, SFEEI, ACCEL, TINC, IIEFTH, SUFFX, OLIISUFFX, OLIIIEFTH, TENSION, IJETW, - IRRagc, UMass) 
THIS SUBROUTINE COMPUTES FOR EACH TTME INCKEMENT THE CTI IIEFTH, THE CTII SPEEII, THE CTII ACCELERATION, ANII THE CAELE TENSION AT THE CTII END OF THE CABLE

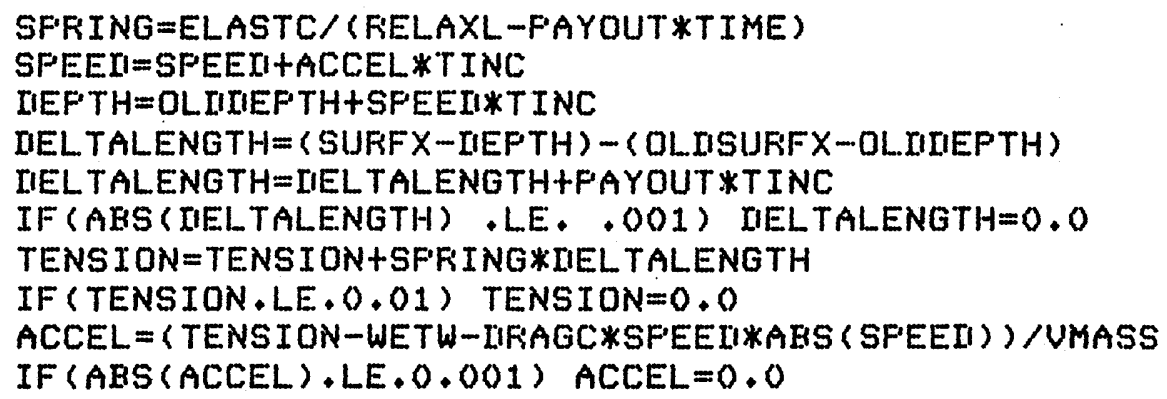

c

FEETURN

ENII

SUEROUTTNE RESULTS (TIME, SURFX, REFTH, SFEEN, ACCEL, TENSION) THIS SUEROUTINE FFINTS, SHEAUE IIISFLACEMENT, CTI IIEFTH, CTI SPEEI, CTI ACCELERATION, ANI CAELE TENSION FOR EACH TIME INCREMENT.

IIEFTH1 $=-$ IIEPTH

IIEPTH2 $=-$ IIEPTH $/ 3.281$

c

URITE $(6,1200)$ TIME, SURFX, DIEPTH1, DIEPTH2, SPEEN, ACCEL, TENSION FORMAT $(1 X, F 6.2,2 X, F 6.2,2 X, F 8.2,2 X, F 7.2,2 X, F 7.2$,

c

\$ $5 X, F 7,2,6 X, F 8,2)$

RETURN

ENI 


\begin{tabular}{|c|c|}
\hline REPORT DOCUMENTATION PAGE & $\begin{array}{l}\text { READ INSTRUCTIONS } \\
\text { BEFORE COMPLETING FORM }\end{array}$ \\
\hline \begin{tabular}{|l|l|} 
1. REPORT NUMBER & 2. GOVT ACCESSION NO. \\
WHOI-83-21 &
\end{tabular} & 3. RECIPIENT'S CATALOG NUMBER \\
\hline $\begin{array}{l}\text { 4. TITLE (and Subtitio) } \\
\text { EXPERIMENTAL EVALUATION OF CTD PACKAGE } \\
\text { HYDRODYNAMIC BEHAVIOR AND RECOMMENDA- }\end{array}$ & $\begin{array}{l}\text { 5. TYPE OF REPORT \& PERIOD COVERED } \\
\text { Technical }\end{array}$ \\
\hline TIONS FOR IMPROVED LOWERING TECHNIQUES & $\begin{array}{l}\text { 6. PERFORMING ORG. REPORT NUMBER } \\
\text { WHOI- } 83-91\end{array}$ \\
\hline $\begin{array}{l}\text { H. O. Berteaux, R. G. Walden, P. R. Clay } \\
\text { and } \\
\text { R.E. McDevitt }\end{array}$ & $\begin{array}{l}\text { B. CONTRACT OR GRANT NUMBER(A) } \\
\text { N00014-72-C-0019 }\end{array}$ \\
\hline $\begin{array}{l}\text { 9. PERFORMING ORGANIZATION NAME AND ADDRESS } \\
\text { Woods Hole Oceanographic Institution } \\
\text { Woods Hole, Massachusetts } 02543\end{array}$ & $\begin{array}{l}\text { 10. PROGRAM ELEMENT, PROJECT, TASK } \\
\text { AREA \& WORK UNIT' NUMBERS }\end{array}$ \\
\hline $\begin{array}{l}\text { 11. CONTROLLING OFFICE NAME ANO ADDRESS } \\
\text { Office of Naval Research }\end{array}$ & $\begin{array}{l}\text { 12. REPORT DATE } \\
\text { July } 1983\end{array}$ \\
\hline & $\begin{array}{l}\text { 13. NUMBER OF PAGES } \\
51\end{array}$ \\
\hline T4. MONITORING AGENCY NAME A ADDRESS(If dilforent from Controlling Offlce) & $\begin{array}{l}\text { 15. SECURITY CLASS. (of this roport) } \\
\text { Unclassified }\end{array}$ \\
\hline & $\begin{array}{l}\text { 15.. DECLASSIFICATION/DOWNGRADING } \\
\text { SCHEDULE }\end{array}$ \\
\hline
\end{tabular}

Approved for public release; distribution unlimited.

17. DISTRIBUTION STATEMENT (oi the abetract ontered in Block 20, 1 difforent from Roport)

18. SUPPLEMENTARY NOTES

This report should be cited: Woods Hole Oceanog. Inst. Tech. Rept. WHOI-83-21.

19. KEY WORDS (Continue on roverte aide /f nocaesary and identity by block number)

1. Instrument Lowering Mechanics

2. CTD Lowering Procedures

3. Cable - Electromechanical Oceanographic Ships

20. ABSTRACT (Continue on roverce ofde if neceseary and identlty by block number)

This report describes the tests performed on scale models and actual CTD packages to actually observe and/or measure their hydrodynamic behavior as they were cable lowered or let free to fall. Analytical results from previous CTD reports (WHOI-79-81 and WHOI-81-76) are combined with these experimental data to draw recommendations for improving present CTD packages and lowering procedures. Suggestions for improved lowering equipment conclude the report. 